\title{
10 Anhang
}

\subsection{Abkürzungen}

ACO Acta Concilorum Oecumenicorum, ed. E. Schwarz / J. Straub u. a, Berlin u. a., seit 1914.

DOC A. R. Bellinger / Ph. Grierson / M. F. Hendy, Catalogue of the Byzantine Coins in the Dumbarton Oaks Collection and in the Whittemore Collection, 5 Bde., Washington 1966-1999.

LSJ H. G. Liddell / R. Scott / H. S. Jones, A Greek-English Lexicon. With a Revised Supplement 1996, Oford 1996

MIB J. Hahn, Moneta Imperii Byzantini, 3 Bde., Wien 1973-1981.

PG Patrologia Cursus Completus, Series Graeca, ed. J.-P. Minge, 162 Bde., Paris 1857-1912.

PL Patrologia Cursus Completus, Series Latina, ed. J.-P. Minge, 221 Bde., Paris 1844-1865.

PLRE A. H. M. Jones / J. R. Martindale / J. Morris, The Prosopography of the Later Roman Empire, 3 Bde., Cambridge u.a. 1992.

PMBZ Prosopographie der mittelbyzantinischen Zeit, nach Vorarbeiten von F. Winkelmann erstellt von R.-J. Lilie / C. Ludwig / Th. Pratsch / I. Rochow / B. Zielke; online verfügbar: https:// www.degruyter.com/view/db/pmbz

\subsection{Quellenverzeichnis}

Alexanderlegende:

- E. A. W. Budge (Ed., Übers.), The History of Alexander the Great. Being the Syriac Version of the Pseudo-Callisthenes. Edited from Five Manuscripts with an English Translation and Notes, Cambridge 1889, $255-275$.

Alexanderlied:

- G. J. Reinink (Ed., Übers.), Das syrische Alexanderlied, 2 Bde., CSCO 454 f., SS 195 f., Leuven 1983. Anastasios der Perser, Vita et translatio reliquiarum:

- B. Flusin (Ed., Übers.), Saint Anastase le Perse et l'histoire de la Palestine au début du VIle siècle, Bd. 1, Paris 1992.

Anthologia Graeca:

- H. Beckby (Ed., Übers.), Anthologia Graeca, griechisch-deutsch, 2. Aufl., Berlin/Boston 1957-1958. Antiochos Strategos (Strategios):

- G. Garitte (Ed., Übers.), La prise de Jérusalem par les Perses en 614, 2 Bde., CSCO 202f., SI 11f., Leuven 1960.

- G. Garitte (Ed., Übers.), Expugnationis Hierosolymae, A.D. 614, Recensiones Arabicae, 4 Bde., CSCO 340 f., 347 f., SA 26-29, Leuven 1973/1974.

- F.C. Conybeare (Übers.), in: English Historical Review 25 (1910), 502 - 517.

Chronicon ad annum 724:

- J.-B. Chabot (Ed., Übers.), Chronicon miscellaneum ad annum Domini 724 pertinens, Chronica Minora 2, CSCO 4, SS 4, Leuven 1955, 63-119.

- A. Palmer (Übers.), The Seventh Century in the West-Syrian Chronicles, Liverpool 1993, 13-23, 49-50.

Chronicon ad annum 1234:

- J.-B. Chabot (Ed., Übers.), Chronicon anonymi auctorus ad annum Christi 1234 pertinens, 3 Bde., CSCO 81f., 109, SS 36 f., 56, Paris 1916-1937; A. Abouna (Übers.), CSCO 345, SS 154, Leuven 1974.

- A. Palmer (Übers.), The Seventh Century in the West Syrian Chronicles, Palmer 1993, 111-221. 


\section{Chronicon Paschale:}

- L. Dindorf (Ed.), Chronicon Paschale, 2 Bde., Bonn 1832.

- Mi. Whitby / Ma. Whitby (Übers.), Chronicon Paschale 284-628 AD, Liverpool 1989.

Chronik von Seert:

- A. Scher (Ed., Übers.), Histoire nestorienne inédite: Chronique de Séert, 4 Bde., Patrologia Orientalis 4.3, 5.2, 7.2, 13.4, Paris $1908-1919$.

Doctrina Jacobi nuper baptizati:

- G. Dagron / V. Déroche (Ed., Übers.), Juifs et chrétiens dans l'Orient du VIl' siècle, Paris 1991, 47 229.

Ekthesis:

- P. Allen (Ed., Übers.), Sophronius of Jerusalem and Seventh-Century Heresy. The Synodical Letter and Other Documents, Oxford 2009, 208-217.

Eutychios:

- M. Bredy (Ed., Übers.), Das Annalenwerk des Eutychios von Alexandrien: Ausgewählte Geschichten und Legenden kompiliert von Sa'id ibn Batriq um 934 AD, 2 Bde., CSCO 471f., SA 44 f., Leuven 1985.

Evagrios Scholastikos:

- A. Hübner (Ed., Übers.), Evagrius Scholasticus. Historia ecclesiastica - Kirchengeschichte, 2 Bde., Turnhout 2007.

- Mi. Whitby (Übers.), The Ecclesiastical History of Evagrius Scholasticus, Liverpool 2000.

Fredegar:

- J. M. Wallace-Hadrill (Ed., Übers.), The Forth Book of the Chronicle of Fredegar with its Continuations, London 1960.

Georg von Pisidien:

- A. Pertusi (Ed., Übers.), Giorgio di Pisidia, Poemi, Bd. I: Panegirici epici, Ettal 1959.

- L. Tartaglia (Ed., Übers.), Carmi di Giorgio di Pisidia, Turin 1998.

Geschichte der Patriarchen von Alexandria:

- B. Evetts (Ed., Übers.), History of the Patriarchs of the Coptic Church of Alexandria, 3 Bde., PO 1.2, 1.4, 5.1, Paris 1907-1910.

Goripp:

- Av. Cameron (Ed., Übers.), Corippus. In laudem Iustini Augusti minoris libri IV, London 1976.

Johannes von Antiochia:

- U. Roberto (Ed., Übers.), Ioannis Antiocheni fragementa ex historia chronica, Berlin u. a. 2005.

- S. Mariev (Ed.), Ioannis Antiocheni fragment aquae supersunt omnia, Berlin/Boston 2008.

Johannes von Nikiu:

- R. H. Charles (Übers.), The Chronicle of John, Bishop of Nikiu, translated from Zotenberg's Ethiopic Text, Oxford 1916.

Khuzistan Chronik (Anonymus Guidi):

- Th. Nöldeke (Übers.), „Die von Guidi herausgegebene syrische Chronik“, Sitzungsberichte der kaiserlichen Akademie der Wissenschaften, phil.-hist. Klasse 128 (1893), 1-48.

Leontios von Neapolis:

- A. J. Festugière (Ed., Übers.), Vie de Symeon le Fou et Jean de Cypre, Paris 1974, 255-637.

Liber Pontificalis:

- L. Duchesne (Ed.), Le Liber Pontificalis: texte, introduction et commentaire, Paris 1955.

- R. Davis (Übers.), The Book of Pontiffs: The Ancient Biographies of the First Ninety Bishops to AD 715, Liverpool 1989.

Michael Syrus:

- J. B. Chabot (Ed., Übers.), Chronique de Michael le Syrien, 4 Bde, Paris 1899-1910.

Movses Dasxuranci:

- C. J. F. Dowsett (Übers.), The History of the Caucasian Albanians by Movses Dasxuranci, London 1961. 
Nikephoros Patriarcha:

- C. Mango (Ed., Übers.), Nikephoros, Patriarch of Constantinople: Short History, Washington, DC 1990.

Prokop von Caesarea:

- J. Haury / G. Wirth (Ed.), Procopii Caesariensis Opera omnia, 4 Bde, Leipzig 1905-1913.

- H. B. Dewing / G. Downey (Ed. / Übers.), Procopius. Buildings, History of the Wars, and Secret History, 7 Bde., Cambridge, MA, 1914-1940.

- 0. Veh. (Ed. / Übers.), Anekdota. Geheimgeschichte am Kaiserhof von Byzanz. Mit Erläuterungen, einer Einführung und Literaturhinweisen von M. Meier und H. Leppin, 4. Aufl., Düsseldorf u. a. 2005.

Ps.-Methodios, Apokalypse:

- G. J. Reinink (Ed., Übers.), Die syrische Apokalypse des Pseudo-Methodius, 2Bde., CSCO 540 f., Scriptores Syri 220 f., Leuven 1993.

Reversio S. Crucis, Sermo de Exaltatione S. Crucis:

- S. Borgehammar (Ed., Übers.), „Heraclius Learns Humility: Two Early Latin Accounts Composed for the Celebration of 'Exaltatio Crucis'“, Millenium-Jahrbuch 6 (2009), 145-202.

Sebeos:

- G. V. Abgaryan (Ed.), Patmut'iwn Sebeosi, Erevan 1979.

- R. W. Thomson / J. Howard-Johnston (Übers.), The Armenian History Attributed to Sebeos, Liverpool 1999.

Sophronios Patriarcha:

- M. Gigante (Ed., Übers.), Sophronii Anacreontica, Rom 1957.

- A. Gallico (Übers.), Sofronio di Gerusalemme: Le omelie, Rom 1991.

- J. de La Ferrière (Übers.), Sophrone de Jérusalem: Fetes chrétiennes à Jérusalem, Paris 1999.

Theodor von Sykeon, Vita:

- A. J. Festugière (Ed., Übers.), Vie de Théodore de Sykéôn, 2 Bde., Brüssel 1970.

Theodor Synkellos:

- F. Combefis (Ed.), „Narratio in depositionem pretiosae vestis Deiparae in Blachernis“, in: Historia haeresis Monothelitarum, Paris 1648, Bd. II, 751-788.

- Av. Cameron (Übers.), „The Virgin's Robe: An Episode in the Hisotry of the Early Seventh-Century Constantinople“, Byzantion 49 (1979), 42-56.

- L. Sternbach (Ed.), „De obsidione Constantinopolis“, in: Analecta Avarica, Krakau 1900, 298-342.

- F. Makk (Übers.), Traduction et Commentaire de l'homélie écrite probablement par Théodore le Syncelle sur le siège de Constantinople en 626, Szeged 1975.

Theophanes Confessor:

- C. de Boor (Ed.), Theophanis Chronographia, Leipzig 1883.

- C. Mango / R. Scott (Übers.), The Chronicle of Theophanes Confessor. Byzantine and Near Eastern History AD 284-813, Oxford 1997.

Theophilos von Edessa:

- R. G. Hoyland (Übers.), Theophilus of Edessa's Chronicle and the Circulation of Historical Knowlegde in Late Antiquity and Early Islam, Liverpool 2014.

Theophylakt Simokattes:

- C. de Boor (Ed.), Theophylacti Simocattae, Historiae, Leipzig 1887.

- P. Schneider (Übers.), Theophylaktos Simokates, Geschichte, Stuttgart 1985.

- Mi. Whitby / Ma. Whitby (Übers.), The History of Theophylact Simocatta, Oxford 1986.

Zeremonienbuch:

- J. J. Reiske (Ed.), De cerimoniis aulae Byzantinae, 2 Bde., CSHB 7 f., Bonn 1829-30.

- A. Moffat / M. Tall (Übers.), Constantine Porphyrogennetos, the Book of Ceremonies. With the Greek edition of the Corpus Scriptorum Historiae Byzantinae (Bonn, 1892), 2 Bde., Canberra 2012. 


\subsection{Literaturverzeichnis}

Akopjan, A. A. (1978), Albanija-Aluak, Erevan.

Alexakis, A. (1995/1996), „Before the Lateran Council of 649: The Last Days of Herakleios the

Emperor and Monotheletism“, Annuarium Historiae Conciliorum 27/28, 93-102.

Alexander, P. J. (1985), The Byzantine Apocalyptic Tradition, Berkeley, CA u.a.

Alföldi, A. (1970), Die monarchische Repräsentation im römischen Kaiserreiche, Darmstadt.

Allen, P. (1981), Evagrius Scholasticus, the Church Historian, Leuven.

Allen, P. (2002), Maximus the Confessor and His Companions. Documents from Exile, Oxford.

Allen, P. (2009), Sophronius of Jerusalem and Seventh-Century Heresy. The Synodical Letter and Other Documents, Oxford.

Antonopoulos, P. T. (2012), „Constans II's Intervention in Italy and its Ideological Significance“, in: J. Koder / I. Stouraitis (Hgg.), Byzantine War Ideology between Roman Imperial Concept and Christian Religion, Wien, 27-32.

Avni, G. (2010), „The Persian Conquest of Jerusalem (614 C.E.) - an Archaeological Assessment“, Bulletin of the American Schools of Oriental Research 357, 35- 48.

Ayaita, J. (2015), Justinian und das Volk im Nikaaufstand, online publ.: https://archiv.ub.uniheidelberg.de/volltextserver/20002/

Baldovin, J. F. (1989), The Urban Character of Christian Worship: The Origins, Development and Meaning of Stational Liturgy, Rom.

Bardill, J. (2006), „A New Temple for Byzantium. Anicia Juliana, King Solomon, and the Gilded Ceiling of the Church of St. Polyeuktos in Constantinople“, in: W. Bowden / A. Gutteridge /

C. Machado (Hgg.), Social and Political Life in Late Antiquity, Leiden, 339-370.

Barišic, F. (1955), „Le siège de Constantinople par les Avares et les Slaves en 626“, Byzantion 24, 371-395.

Barkhuizen, J. H. (1995), „Romanos Melodos: On Earthquakes and Fires“, Jahrbuch der österreichischen Byzantinistik 45, 1-18.

Bayliss, R. I. / Crow, J. G. (2002), „The Water Supply of Constantinople“, Anatolian Archaeology 8, 21-23.

Baynes, N. H. (1904), „The First Campaign of Heraclius against Persia“, The English Historical Review 19, 694-702.

Baynes, N. H. (1912a), „The Restoration of the Cross at Jerusalem“, The English Historical Review 27, 287-299.

Baynes, N. H. (1912b), „The Date of the Avar Surprise“, Byzantinische Zeitschrift 21, 110-128.

Baynes, N. H. (1949), „The Supernatural Defenders of Constantinople“, Analecta Bollandiana 67, $165-77$.

Baynes, N. H. (1952), „The Emperor Heraclius and the Military Theme System“, The English Historical Review 67, 380-381.

Beaucamp, J. (1979), „Temps et Histoire I: Le prologue de la 'Chronique pascale’“, Travaux et Mémoires 7, 223-302.

Begass, C. (2018), Die Senatsaristokratie des Oströmischen Reiches, ca. 457-518, München.

Begass, C. (2021), Senat II (Konstantinopel), Reallexikon für Antike und Christentum, Bd. 30, $294-311$.

Bell, P. N. (2009), Three Political Voices from the Age of Justinian. Agapetus: Advice to the emperor, Dialogue on political science, Paul the Silentiary: Description of Hagia Sophia, Liverpool.

Bellinger, A. R. (1966), „Byzantine Notes 10: Solidi of Heraclius and Heraclius Constantine“, American Numismatic Society. Museum Notes 12, $109 \mathrm{f}$.

Bijovski, G. (2010), „A Single Die Solidi Hoard of Heraclius from Jerusalem“, in: Mélanges Céciles Morrisson, Travaux et Memoirs 16, Paris, 55-92. 
Blockley, R. C. (1985), „Subsidies and Diplomacy: Rome and Persia in Late Antiquity“, Phoenix 39, $62-74$.

Boak, A. E. R. (1919), „Imperial Coronation Ceremonies of the Fifth and Sixth Centuries“, Harvard Studies in Classical Philology, 37-47.

Bonner, M. R. J. (2020), The Last Empire of Iran, Piscataway.

Booth, P. (2013a), „Sophronius of Jerusalem and the End of Roman History“, in: P. Wood. (Hg.), History and Identity in the Late Antique Near East, Oxford, 1-27.

Booth, P. (2013b), „The Muslim Conquest of Egypt Reconsidered“, in: C. Zuckerman (Hg.), Constructing the Seventh Century, Travaux et Mémoires 17, Paris, 639-669.

Booth, P. (2014), Crisis of Empire. Doctrine and Dissent at the End of Late Antiquity, Berkeley, CA. Booth, P. (2016), „The Last Years of Cyrus, Patriarch of Alexandria“, in: J.-L. Fournet, / A. Papaconstantinou (Hgg.), Mélanges Jean Gascou, Textes et études papyrologiques, Paris, $509-558$.

Booth, P. (2019), „The Ghost of Maurice at the Court of Heraclius“, Byzantinische Zeitschrift 112.3, 781-826.

Borgehammar, S. (1991), How the Holy Cross was Found. From Event to Medieval Legend, Stockholm.

Borgehammar, S. (2009), „Heraclius Learns Humility: Two Early Latin Accounts Composed for the Celebration of 'Exaltatio Crucis'“, Millennium-Jahrbuch 6, 145-202.

Börm, H. (2010), „Herrscher und Eliten in der Spätantike“, in: H. Börm (Hg.), Commutatio et Contentio. Studies in the Late Roman, Sasanian and Early Islamic Near East. In memory of Zeev Rubin, Düsseldorf, 159-198.

Börm, H. (2013), „Justinians Triumph und Belisars Erniedrigung. Überlegungen zum Verhältnis zwischen Kaiser und Militär im späten Römischen Reich“, Chiron 43, 63-91.

Börm, H. (2015a), „Born to be Emperor. The Principle of Succession and the Roman Monarchy“, in: J. Wienand (Hg.), Contested Monarchy: Integrating the Roman Empire in the 4th Century AD, Oxford, 239-264.

Börm, H. (2015b), „Procopius, His Predecessors, and the Genesis of the Anecdota. Antimonarchic Discourse in Late Antique Historiography“, in: H. Börm (Hg.), Antimonarchic Discourse in Antiquity, Stuttgart, 305-346.

Börm, H. (2016), „A Threat or a Blessing? The Sasanians and the Roman Empire“, in: ders. / C. Binder / A. Luther (Hgg.), Diwan. Studies in the History and Culture of the Ancient Near East and the Eastern Mediterranean, Duisburg, 615-646.

Börm, H. (2018), Westrom von Honorius bis Justinian, 2. Aufl., Stuttgart.

Brandes, W. (1989), Die Städte Kleinasiens im 7. und 8. Jahrhundert, Amsterdam.

Brandes, W. (1990), „Die apokalyptische Literatur“, in: ders. / F. Winkelmann (Hgg.), Quellen zur Geschichte des frühen Byzanz (4.-9. Jahrhundert), Berlin, 305-322.

Brandes, W. (1993), „Familienbande? Odoaker, Basiliskos und Harmatios“, Klio 75, 407-437.

Brandes, W. (1997), „Anastasios ,0 dikoros‘: Endzeiterwartung und Kaiserkritik in Byzanz um 500 n. Chr.“, Byzantinische Zeitschrift 90, 24-63.

Brandes, W. (2002a), „Heraclius between Restoration and Reform. Some Remarks on Recent Research“, in: G. J. Reinink / B. H. Stolte (Hgg.), The Reign of Heraclius (610-641). Crisis and Confrontation, Leuven, 17-40.

Brandes, W. (2002b), Finanzverwaltung in Krisenzeiten: Untersuchungen zur byzantinischen Administration im 6. -9. Jahrhundert, Frankfurt a. M.

Brandes, W. (2014), „Der Nika-Aufstand, Senatorenfamilien und Justinians Bauprogramm“, in: M. Meier / S. Patzold (Hgg.), Chlodwigs Welt. Organisation von Herrschaft um 500, Stuttgart, $239-268$.

Bredy, M. (1985), Das Annalenwerk des Eutychios von Alexandrian. Ausgewählte Geschichten und Legenden kompiliert von Sa'id ibn Batriq um 935 A.D., Leuven. 
Brodka, D. (2004), Die Geschichtsphilosophie in der spätantiken Historiographie: Studien zu Prokopios von Kaisareia, Agathias von Myrina und Theophylaktos Simokattes, Frankfurt a.M.

Brubaker, L. (2001), „Topography and the Creation of Public Space in Early Medieval

Constantinople“, in: M. de Jong (Hg.), Topographies of Power in the Early Middle Ages, Leiden u. a., 31- 43.

Budge, E. A. W. (1889), The History of Alexander the Great. Being the Syriac Version of the Pseudo-Callisthenes. Edited from Five Manuscripts with an English Translation and Notes, Cambridge.

Burgess, R. W. (1993/94), „The Accession of Marcian in the Light of Chalcedonian Apologetic and Monophysite Polemic“, Byzantinische Zeitschrift 86/87, 47-68.

Bury, J. B. (1930), The Constitution of the Later Roman Empire, Cambridge.

Cameron, Al. (1976), Circus Factions: Blues and Greens at Rome and Byzantium, Oxford.

Cameron, Av. (1967), „Notes on the Sophiae, the Sophianae, and the Harbour of Sophia“, Byzantion 37, $11-20$.

Cameron, Av. (1975), „The Empress Sophia“, Byzantion 45, 5- 21.

Cameron, Av. (1976a), Corippus. In laudem Iustini Augusti minoris libri IV, London.

Cameron, Av. (1976b), „An Emperor’s Abdication“, Byzantinoslavica 37, 161-167.

Cameron, Av. (1976c), „The Early Religious Policies of Justin II“, in: D. Baker (Hg.), The Orthodox Churches and the West, Oxford, 51-67.

Cameron, Av. (1977), „Early Byzantine Kaiserkritik: Two Case Histories“, Byzantine and Modern Greek Studies 3, 1-17.

Cameron, Av. (1978), „The Theotokos in Sixth-Century Constantinople: A City Finds Its Symbol“, The Journal of Theological Studies 29, 79-108.

Cameron, Av. (1979a), „The Virgin's Robe: An Episode in the History of Early Seventh-Century Constantinople“, Byzantion 49, 42-56.

Cameron, Av. (1979b), „Images of Authority: Elites and Icons in Late Sixth-Century Byzantium“, Past and Present 84, 3-35.

Cameron, Av. (1980), „The Artistic Patronage of Justin II“, Byzantion 50, 62-84.

Cameron, Av. (1981), Continuity and Change in Sixth-Century Byzantium, London.

Cameron, Av. (1994), „The Jews in Seventh-Century Palestine“, Scripta classica Israelica 13, 75-93.

Cameron, Av. (1996a), Procopius and the Sixth Century, London/New York.

Cameron, Av. (1996b), Changing Cultures in Early Byzantium, Aldershot.

Cameron, Av. (2002), „The 'Long' Late Antiquity: a Late Twentieth Century Model“, in: T. P. Wiseman (Hg.), Classics in Progress, Oxford, 165-192.

Cameron, Av. (2004), „Democratization Revisited - Culture and Late Antique and Early Byzantine Elites“, in: J. Haldon (Hg.), Elites Old and New in the Byzantine and Early Islamic Near East, Studies in Late Antiquity and Early Islam, Princeton, NJ, 91-107.

Cameron, Av. (2012), The Mediterranean World in Late Antiquity 395-700 AD, 2. Aufl., London u. a.

Cameron, Av. (2017), „Late Antique Apocalyptic: A Context for the Quran?“, in: H. Amirav /

E. Grypeou / G. G. Stroumsa (Hgg.), Apocalypticism and Eschatology in Late Antiquity, Leuven u. a., 1-20.

Canepa, M. P. (2009), The Two Eyes of the Earth: Art and Ritual of Kingship between Rome and Sasanian Iran, Berkeley, CA u. a.

Charles, R. H. (1916), The Chronicle of John, Bishop of Nikiu. Translated from Zotenberg's Ethiopic Text, London u.a.

Chrysos, E. K. (1978), „The Title Basileus in Early Byzantine International Relations“, Dumbarton Oaks Papers 32, 29-75.

Collins, R. (2007), Die Fredegar-Chroniken, Hannover.

Conybeare, F. C. (1910), „Antiochus Strategos' Account of the Sack of Jerusalem in A. D. 614“, The English Historical Review 25, 502-517. 
Corsi, P. (1975), „La spedizione in Italia di Costante II: fonti e problemi“, Nicolaus. Rivista di teologia ecumenico-patristica 3, 343-392.

Croke, B. (2003), „The Imperial Reigns of Leo II“, Byzantinische Zeitschrift 96, 559-576.

Croke, B. (2005a), „Dynasty and Ethnicity: Emperor Leo I and the Eclipse of Aspar“, Chiron 35, $147-204$.

Croke, B. (2005b), „Leo I and the Palace Guard“, Byzantion 75, 117-151.

Croke, B. (2007), „Justinian under Justin: Reconfiguring a Reign“, Byzantinische Zeitschrift 100, $13-56$.

Croke, B. (2008), „Poetry and Propaganda: Anastasius I as Pompey“, Greek, Roman and Byzantine Studies 48, 447- 466.

Crow, J. G. (2006), „Der Anastasische Wall: ,Die letzte Grenze““, in: G. Klose (Hg.), Grenzen des Römischen Imperiums, Mainz, 181-187.

Dagron, G. (1974), Naissance d'une capitale. Constantinople et ses institutions de 330 à 451, Paris.

Dagron, G. (2003), Emperor and Priest. The Imperial Office in Byzantium, Cambridge.

Dagron, G. / Déroche, V. (2010), Juifs et chrétiens en Orient byzantin, Paris.

Dawes, E. H. S. / Baynes, N. H. (1948), Three Byzantine Saints: Contemporary Biographies of St. Daniel the Stylite, St. Theodore of Sykeon, and St. John the Almsgiver, Crestwood, N.Y.

Delehaye, H. (1902), Synaxarium Ecclesiae Constantinopolitanae, Brüssel.

Demandt, A. (1970), „Magister militum“, in: Paulys Realencyclopädie, Suppl. 12, Sp. 553-790.

Demandt, A. (1980), „Der Spätrömische Militäradel“, Chiron 10, 609-636.

Demandt, A. (2007), Handbuch der Altertumswissenschaft: Die Spätantike, 2. Aufl., München.

De Vleeschouwer, A. (2019), „The Foreign Policy of Phocas (602-610): A Neorealist Reassessment“, Byzantion 89, $415-462$.

Diefenbach, S. (1996), „Frömmigkeit und Kaiserakzeptanz im frühen Byzanz“, Saeculum 47, 35-66.

Diefenbach, S. (2002), „Zwischen Liturgie und civilitas. Konstantinopel im 5. Jahrhundert und die Etablierung eines städtischen Kaisertums“, in: R. Warland (Hg.), Bildlichkeit und Bildorte von Liturgie. Schauplätze in Spätantike, Byzanz und Mittelalter, Wiesbaden, 21-49.

Diefenbach, S. (2012), „Constantius II. und die ,Reichskirche‘: Ein Beitrag zum Verhältnis von kaiserlicher Kirchenpolitik und politischer Integration im 4. Jh.“, Millennium Jahrbuch 9 , 59-121.

Diefenbach, S. (2019), „Zur Dynamik kaiserlicher Siegesrituale in der Spätantike. Konstantinopel und Rom im Vergleich“, in: R. Conrad / V. H. Drecoll / S. Hirbodian (Hgg.), Säkulare Prozessionen. Zur religiösen Grundierung von Umzügen, Einzügen und Aufmärschen, Tübingen, 63-110.

Dölger, F. (1976), Regesten der Kaiserurkunden des Oströmischen Reiches von 565-1453. Drei Teile in einem Band, Hildesheim.

Donner, F. M. (1981), The Early Islamic Conquests, Princeton, NJ.

Dowsett, C. J. F. (1961), Movses Dasxuranci. The History of the Caucasian Albanians, London.

Drijvers, J. W. (1992), Helena Augusta: the Mother of Constantine the Great and the Legend of her Finding of the True Cross, Leiden u. a.

Drijvers, J. W. (2002), „Heraclius and the Restitutio Crucis. Notes on Symbolism and Ideology“, in: G. J. Reinink / B. Stolte (Hg.), The Reign of Heraclius (610-641). Crisis and Confrontation, Leuven, 175-190.

Efthymiadis, S. (2010), „A Historian and His Tragic Hero: A Literary Reading of Theophylact Simokatta's Ecumenical History“, in: R. Macrides (Hg.), History as Literature in Byzantium, Farnham, 169-186.

Ekonomou, A. J. (2007), Byzantine Rome and the Greek Popes: Eastern Influences on Rome and the Papacy from Gregory the Great to Zacharias, A.D. 590-752, Lanham, Md. u. a.

Elm, E. (2012), „Memoriae damnatio“, Reallexikon für Antike und Christentum 24, Sp. 657-682. 
Ensslin, W. (1943/49), „Zur Frage der ersten Kaiserkönungen in Byzanz durch den Patriarchen und zur Bedeutung dieses Aktes im Zeremoniell“, Byzantinische Zeitschrift 42, 101-115, 369-372.

Ericsson, K. (1968), „Revising a Date in the Chronicon Paschale“, Jahrbuch der österreichischen byzantinischen Gesellschaft 17, 17-28.

Errington, R. M. (1983), „Malchos von Philadelphia, Kaiser Zenon und die zwei Theoderiche“, Museum Helveticum 40, 82-110.

Esders, S. (2009), „Herakleios, Dagobert und die ,beschnittenen Völker““, in: A. Goltz / H. Leppin / H. Schlange-Schöningen (Hgg.), Jenseits der Grenzen. Beiträge zur spätantiken und frühmittelalterlichen Geschichtsschreibung, Berlin/Boston, 239-312.

Esders, S. (2018), „The Prophesied Rule of a 'Circumcised People': A Travelling Tradition from the Seventh-Century Mediterranean“, in: Y. Hen / T. F. X. Noble (Hgg.), Barbarians and Jews. Jews and Judaism in the Early Medieval West, Turnhout, 119-154.

Evetts, B. (1907-1910), History of the Patriarchs of the Coptic Church of Alexandria, Paris.

Faber, E. (2011), „Anti-Germanism in Constantinople or the Revolt of Gainas?“, in: D. Hernández de la Fuente (Hg.), New Perspectives on Late Antiquity, Newcastle upon Tyne, 124-135.

Ferrière, J. de la (1999), Sophrone de Jérusalem. Fêtes chrétiennes à Jérsualem, Paris.

Festugière, A. J. (1970), Vie de Théodore de Sykéon, Brüssel.

Festugière, A. J. (1974), Vie de Symeon le Fou et Jean de Cypre, Paris.

Fischer-Lichte, E. (2003), „Performance, Inszenirung, Ritual: zur Klärung kulturwissenschaftlicher Schlüsselbegriffe“, in: J. Martschukat, / S. Patzold (Hgg.), Geschichtswissenschaft und „performative turn“. Ritual, Inszenierung und Performanz vom Mittelalter bis zur Neuzeit, Köln u. a., 33-54.

Flaig, E. (1992), Den Kaiser herausfordern: Die Usurpation im Römischen Reich, Frankfurt a. M.

Flaig, E. (1997), „Für eine Konzeptionalisierung der Usurpation im Spätrömischen Reich“, in: F. Paschoud / J. Szidat (Hgg.), Usurpationen in der Spätantike, Stuttgart, 15-34.

Flaig, E. (2007), „,Heiliger Krieg‘. Auf der Suche nach einer Typologie“, Historische Zeitschrift 285, $265-302$.

Flusin, B. (1992), Saint Anastase le Perse et l'histoire de la Palestine au début du VIle siècle, 2 Bde., Paris.

Fowden, G. (1993), Empire to Commonwealth: Consequences of Monotheism in Late Antiquity, Princeton, NJ.

Fowden, G. (2014), Before and after Muhammad: The First Millennium Refocused, Princeton, NJ.

Frank, R. (1969), Scholae palatinae: The Palace Guards of the Later Roman Empire, Rom.

Frend, W. H. C. (1972), The Rise of the Monophysite Movement: Chapters in the History of the Church in the Fifth and Sixth Centuries, Cambridge.

Frendo, J. D. C. (1984) „The Poetic Achievement of George of Pisidia: A Literary and Historical Study“, in: A. Moffatt (Hg.), Studies Robert Browning, Canberra, 159-187.

Frendo, J. D. C. (1988a), „History and Panegyric in the Age of Heraclius: the Literary Background to the Composition of the Histories of Theophylact Simocatta“, Dumbarton Oaks Papers 42, $143-156$.

Frendo, J. D. C. (1988b), „Religion and Politics in Byzantium on the Eve of the Arab Conquest“, Florilegium 10, 1-23.

Frendo, J. D. C. (2001), „Three Authors in Search of a Reader: An Approach to the Analysis of Direct Discourse in Procopius, Agathias and Theophylact Simocatta“, in: C. Sode / S. Takács (Hgg.), Novum Millennium: Studies on Byzantine History and Culture Dedicated to Paul Speck, Aldershot, 123-136.

Frolow, A. (1944), „La dédicace de Constantinople dans la tradition byzantine“, Revue de l'histoire des religions 127, 61-127.

Frolow, A. (1953), „La Vraie Croix et les expéditions d’Héraclius en Perse“, Revue des études byzantines 11, 89-105. 
Gallico, A. (1991), Sofronio di Gerusalemme. Le omelie, Rom.

Garland, L. (1999), Byzantine Empresses: Women and Power in Byzantium, AD 527-1204, London. Gehrke, H.-J. (1982), „Der siegreiche König. Überlegungen zur hellenistischen Monarchie“, Archiv für Kulturgeschichte 64, 247-277.

Gigante, M. (1957), Sophronii Anacreontica, Roma.

Girardet, C. M. (1980), „Das christliche Priestertum Konstantins d. Gr. Ein Aspekt der Herrscheridee des Eusebius von Caesarea“, Chiron 10, 569-592.

Gluschanin, E. P. (1991), Der Militäradel des frühen Byzanz, Barnaul.

Gräbner, M. (1982), „Maurikie Markianista“, Byzantina 11, 181-188.

Greatrex, G. (1997), „The Nika Riot: A Reappraisal“, The Journal of Hellenic Studies 117, 60-86.

Greatrex, G. / Lieu, S. N. C. (2002), The Roman Eastern Frontier and the Persian Wars. A Narrative Sourcebook, Bd. 2: AD 363-630, London.

Greisiger, L. (2013), „The Last Roman-Persian War of 602-28: Near Eastern and Constantinopolitan Fears and Hopes“, in: R. Alciati / F. Fatti (Hgg.), La controversia origenista: un affare mediterraneo. L'esperienza religiosa della crisi nel mondo mediterraneo, IV-VII sec., Brescia, $359-370$.

Greisiger, L. (2014), Messias - Endkaiser - Antichrist: politische Apokalyptik unter Juden und Christen des Nahen Ostens am Vorabend der arabischen Eroberung, Wiesbaden.

Greisiger, L. (im Druck), „From 'King Heraclius, faithful in Christ' to ‘Allenby of Armageddon': Christian Reconquistadores Enter the Holy City“, in: K. Klein / J. Wienand (Hgg.), City of Caesar, City of God: Constantinople and Jerusalem in Late Antiquity.

Grierson, P. (1950a), „Dated Solidi of Maurice, Phocas, and Heraclius“, in: The Numismatic Chronicle 10, 49-70.

Grierson, P. (1950b), „The Consular Coinage of Heraclius and the Revolt against Phocas of 608-610“, The Numismatic Chronicle 10, 71-93.

Grierson, P. (1959), „Solidi of Phocas and Heraclius: The Chronological Framework“, The Numismatic Chronicle 19, 131-154.

Grumel, V. (1966), „La Reposition de la vraie Croix à Jérusalem par Héraclius. Le Jour et l’Année“, Byzantinische Forschungen 1, 139-149.

Guran, P. (2009), „The Constantinople - New Jerusalem at the Crossing of Sacred Space and Political Theology“, in: A. M. Lidov (Hgg.), The Constantinople - New Jerusalem at the Crossing of Sacred Space and Political Theology, Moskau, 35-57.

Haldon, J. F. (1984), Byzantine Praetorians: An Administrative, Institutional and Social Survey of the Opsikion and Tagmata, c. 580-900, Bonn.

Haldon, J. F. (1990), Byzantium in the Seventh Century: The Transformation of a Culture, Cambridge / New York.

Haldon, J. F. (1994), „Constantine or Justinian? Crisis and Identity in Imperial Propaganda in the Seventh Century“, in: P. Magdalino (Hg.), New Constantines. The Rhythm of Imperial Renewal in Byzantium, $4^{\text {th }}-13^{\text {th }}$ Centuries, Aldershot, 95-107.

Haldon, J. F. (2002), „The Reign of Heraclius. A Context for Change?“, in: G. J. Reinink / B. Stolte (Hgg.), The Reign of Heraclius (610-641). Crisis and Confrontation, Leuven, 1-16.

Haldon, J. F. (2004), „The Fate of the Late Roman Senatorial Elite: Extinction or Transformation“, in: ders. / L. I. Conrad (Hgg.), Elites Old and New in the Byzantine and Early Islamic Near East, Princeton, NJ.

Haldon, J. F. (2016), The Empire that Would not Die. Eastern Roman Survival, 640-740, Cambridge, Mass. u.a.

Halsall, G. (2002), Humour, History and Politics in Late Antiquity and the Early Middle Ages, Cambridge.

Hammond, N. G. L. (1996), „The Construction of Xerxes’ Bridge over the Hellespont“, The Journal of Hellenic Studies 116, 88-107. 
Havener, W. (2016), Imperator Augustus. Die diskursive Konstituierung der militärischen „persona“ des ersten römischen „princeps“, Stuttgart.

Hebblewhite, M. (2017), The Emperor and the Army in the Later Roman Empire, AD 235-395, London.

Hendy, M. F. (1985), Studies in the Byzantine Monetary Economy c. 300-1450, Cambridge u.a. Henning, D. (1999), Periclitans res publica: Kaisertum und Eliten in der Krise des weströmischen Reiches 454/5-493 n. Chr., Stuttgart.

Herrin, J. (1987), The Formation of Christendom, Princeton, NJ.

Höfert, A. (2015), Kaisertum und Kalifat: der imperiale Monotheismus im Früh- und Hochmittelalter, Frankfurt a.M. u.a.

Hölkeskamp, K.-J. (2015), „,Performative turn“ meets ,spatial turn‘. Prozessionen und andere Rituale in der neueren Forschung“, in: D. Boschung, K.-J. Hölkeskamp, C. Sode (Hgg.), Raum und Performanz. Rituale in Residenzen von der Antike bis 1815, Stuttgart, 15-74.

Hovorun, C. (2008), Will, Action, and Freedom: Christological Controversies in the Seventh Century, Leiden.

Howard-Johnston, J. (1992), „The Official History of Heraclius’ Persian Campaigns“, in: E. Dąbrowa (Hg.), The Roman and Byzantine Army in the East, Krakau, 57-87.

Howard-Johnston, J. (1999), „Heraclius' Persian Campaigns and the Revival of the Eastern Roman Empire, 622-630“, War in History 6/1, 1-44.

Howard-Johnston, J. (2010), Witnesses to a World Crisis: Historians and Histories of the Middle East in the Seventh Century, Oxford.

Howard-Johnston, J. (2002), „Armenian Historians of Heraclius. An Examination of the Aims, Sources and Working-Methods of Sebeos and Movses Daskhurantsi“, in: G. J. Reinink / B. Stolte (Hgg.), The Reign of Heraclius (610-641). Crisis and Confrontation, Leuven, 41-62. Howard-Johnston, J. (2006), East Rome, Sasanian Persia and the End of Antiquity: Historiographical and Historical Studies, Ashgate.

Howard-Johnston, J. (im Druck), „Jerusalem in 630“, in: K. Klein / J. Wienand (Hgg.), City of Caesar, City of God: Constantinople and Jerusalem in Late Antiquity.

Hoyland, R. (1997), Seeing Islam as Others Saw it: A Survey and Evaluation of Christian, Jewish, and Zoroastrian Writings on Early Islam, Princeton, NJ.

Hoyland, R. (2011), Theophilus of Edessa's Chronicle and the Circulation of Historical Knowledge in Late Antiquity and Early Islam, Liverpool.

Hübner, A. (2007), Evagrius Scholasticus, Historia ecclesiastica, Turnhout.

Hunger, H. (1978), Die hochsprachliche profane Literatur der Byzantiner, Bd. 1: Philosophie, Rhetorik, Epistolographie, Geschichtsschreibung, Geographie, München.

Hurbanic, M. (2011), „The Eastern Roman Empire and the Avar Khaganate in the Years 622-624

AD“, Acta antiqua Academiae Scientiarum Hungaricae 51, 315-328.

Hurbanic, M. (2016), „Adversus ludaeos in the Sermon Written by Theodore Syncellus on the Avar Siege of AD 626“, Studia Ceranea 6, 271-293.

Hurbanic, M. (2019), The Avar Siege of Constantinople in 626. History and Legend, Cham. Huttner, U. (2004), Recusatio Imperii: ein politisches Ritual zwischen Ethik und Taktik, Hildesheim. Janin, R. (1969), Le géographie ecclésiastique de l'empire Byzantin, Bd. 1: Le siège de Constantinople et le patriarcat Oecuménique, Bd. 3: Les églises et les monastère, Paris. Jankowiak, F. (2013), „The First Arab Siege of Constantinople“, in: C. Zuckermann (Hgg.), Constructing the Seventh Century, Travaux et Mémoirs 17, Paris, 237-322.

Jones A. H. M. (1956), „Numismatics and History“, in: R. A. G. Carson / C. H. V. Sutherland (Hgg.), Essays in Roman Coinage Presented to Harold Mattingly, Oxford, 13-33.

Jones A. H. M. (1964), The Later Roman Empire 284-602, 2 Bde., Oxford.

Kaegi, W. E. (1968), Byzantium and the Decline of Rome, Princeton, NJ. 
Kaegi, W. E. (1973), „New Evidence for the Early Reign of Heraclius“, Byzantinische Zeitschrift 66, $308-330$.

Kaegi, W. E. (1981), Byzantine Military Unrest, 471-843: An Interpretation, Amsterdam.

Kaegi, W. E. (1992), Byzantium and the Early Islamic Conquests, Cambridge.

Kaegi, W. E. (2000), „A Misunderstood Place-Name in a Poem of George of Pisidia“, Byzantinische Forschungen 26, $229 \mathrm{f}$.

Kaegi, W. E. (2003), Heraclius, Emperor of Byzantium, Cambridge/New York.

Kalavrezou, I. (2003), Byzantine Women and Their World, Cambridge, Mass.

Kaldellis, A. (2004), Procopius of Caesarea. Tyranny, History, and Philosophy at the End of Antiquity, Philadelphia, PA.

Kaldellis, A. (2019), Romanland. Ethnicity and Empire in Byzantium, Cambridge, MA u. a.

Karayannopulos, J. E. (1959), Die Entstehung der byzantinischen Themenordnung, München.

Kelly, C. (2004), Ruling the Later Roman Empire, Cambridge, Mass. u. a.

Kelly, C. (2013), „Stooping to Conquer: The Power of Imperial Humility“, in: C. Kelly (Hg.), Theodosius II: Rethinking the Roman Empire in Late Antiquity, Cambridge, 221-243.

Kiel-Freytag, A. (2010), „Betrachtungen zur Usurpation des Illus und des Leontius (484-488 n. Chr.)“, Zeitschrift für Papyrologie und Epigraphik 174, 291-301.

Kirch, C. (1901), „Nicephori sceuophylacis encomium in S. Theodorum Siceotam“, Analecta Bollandiana 20, 249-272.

Klein, H. A. (2001), „Niketas und das wahre Kreuz“, Byzantinische Zeitschrift 94, 580-587.

Klein, H. A. (2004), Byzanz, der Westen und das „wahre“ Kreuz: die Geschichte einer Reliquie und ihrer künstlerischen Fassung in Byzanz und im Abendland, Wiesbaden.

Klein, H. A. (2006), „Sacred Relics and Imperial Ceremonies at the Great Palace of Constantinople“, in: F. A. Bauer (Hg.), Visualisierungen von Herrschaft. Frühmittelalterliche Residenzen, Gestalt und Zeremoniell, Istanbul, 79-100.

Koder, J. (1999), „Romanos Melodos und sein Publikum. Zur Einbeziehung und Beeinflussung der Zuhörer durch das Kontakion“, Österreichische Akademie der Wissenschaften. Anzeiger phil.-hist. Klasse 134, 63-94.

Koder, J. (2005), Romanos Melodos. Die Hymnen, 2 Bde., Stuttgart 2005.

Koehn, C. (2018), Justinian und die Armee des frühen Byzanz, Berlin u. a.

Kolb, F. (2001), Herrscherideologie in der Spätantike, 2001.

Kolbaba, T. M., (1998), „Fighting for Christianity. Holy War in the Byzantine Empire“, Byzantion 68, $194-221$.

Kolditz, S. (2013), „Ein umstrittener Kaiser und patriarchale Kirchen im späteren fünften Jahrhundert: Weltliche und geistliche Macht unter Basiliskos“, in: M. Grünbart / L. Rickelt (Hg.), Zwei Sonnen am Goldenen Horn?, Bd. 2, Berlin u.a., 19-54.

Konidaris, I. M. (1982), „Die Novellen des Kaisers Herakleios“, Fontes Minores 5, Forschungen zur byzantinischen Rechtsgeschichte 8, 33-106.

Köpstein, H. (1978), „Das 7. Jahrhundert (565-711) im Prozess der Herausbildung des Feu- dalismus in Byzanz", in: dies. / F. Winkelmann / H. Ditten / I. Rochow (Hgg.), Byzanz im 7. Jahrhundert. Untersuchungen zur Herausbildung des Feudalismus, Berlin, 289-301.

Koschorke, A. (2012), Wahrheit und Erfindung: Grundzüge einer allgemeinen Erzähltheorie, 2. Aufl., Frankfurt.

Koselleck, R. (1973), „Ereignis und Struktur“, in: ders. / W.-D. Stempel (Hgg.), Geschichte - Ereignis und Erzählung, München, 581-599.

Kosinski, R. (2010), The Emperor Zeno: Religion and Politics, Krakau.

Kosinski, R. (2016), Holiness and Power: Constantinopolitan Holy Men and Authority in the $5^{\text {th }}$ Century, Berlin u.a.

Krause, J.-U. (2013), „Die Spätantike (284-565 n. Chr.)“, in: H.-J. Gehrke / H. Schneider (Hgg.), Geschichte der Antike. Ein Studienbuch, 4. Aufl., Stuttgart/Weimar, 429-499. 
Kresten, O. (2000), „Herakleios und der Titel basileus“, Varia 7, $178 \mathrm{f}$.

Kuhoff, W. (2012), „Die Versuchung der Macht. Spätrömische Heermeister und ihr potentieller Griff nach dem Kaisertum“, in: S. S. Tschopp / W. E. J. Weber (Hgg.), Macht und Kommunikation, Berlin, 39-80.

Külzer, A. (2000), „Konstantinopel in der apokalyptischen Literatur der Byzantiner“, Jahrbuch der österreichischen Byzantinistik 50, 51-76.

Lange, C. (2012), Mia Energeia: Untersuchungen zur Einigungspolitik des Kaisers Heraclius und des Patriarchen Sergius von Constantinopel, Tübingen.

Larison, D. (2019), „George of Pisdia and Contra Severum: Panegyric and Polemic as Source for Interpreting Religious Policy“, in: Ch. Raffensperger / D. M. Olster (Hgg.), Radical Traditionalism. The Influence of Walter Kaegi in Late Antique, Byzantine, and Medieval Studies, London, 163-180.

Lauxtermann, M. D. (2003), Byzantine Poetry from Pisides to Geometres: Texts and Contexts, Bd. 1, Wien.

Lauxtermann, M. D. (2019), Byzantine Poetry from Pisides to Geometres: Texts and Contexts, Bd. 2, Wien.

Leader, R. E. (2000), „The David Plates Revisited: Transforming the Secular in Early Byzantium“, The Art Bulletin 82, 407-427.

Lee, A. D. (2007), War in Late Antiquity: A Social History, Oxford.

Lee, A. D. (2015), „Emperors and Generals in the Fourth Century“, in: J. Wienand (Hg.), Contested Monarchy: Integrating the Roman Empire in the $4^{\text {th }}$ Century AD, Oxford, 100-118.

Lemerle, P. (1979/81), Les plus anciens recueils des miracles de Saint Démétrius et la pénétration des Slaves dans les Balkans, 2 Bde., Paris.

Lenski, N. (1997), „Initium mali Romano imperio. Contemporary Reactions to the Battle of Adrianople“, Transactions of the American Philological Association 127, 129-168

Leppin, H. (2003), Theodosius der Große, Darmstadt.

Leppin, H. (2007), „Das Alte Testament und der Erfahrungsraum der Christen. Davids Buße in den Apologien des Ambrosius“, in: A. Peçar / K. Trampedach (Hgg.), Die Bibel als politisches Argument. Voraussetzungen und Folgen, München, 119-134.

Leppin, H. (2011), Justinian: Das christliche Experiment, Stuttgart.

Leppin, H. (2013), „Kaisertum und Christentum in der Spätantike: Überlegungen zu einer unwahrscheinlichen Sythese“, in: A. Fahrmeir / A. Irmhausen (Hgg.), Die Vielfalt normativer Ordnungen. Konflikte und Dynamik in historischer und ethnologischer Perspektive, Frankfurt a. M., 197-223.

Leppin, H. (2015), „Coping with the Tyrant’s Faction“, in: J. Wienand (Hg.), Contested Monarchy. Integrating the Roman Empire in the Fourth Century AD, Oxford, 198-214.

Leppin, H. (2017), „Das 4. Jahrhundert - Die christlichen Kaiser suchen ihren Ort“, in: S. Rebenich (Hg.), Monarchische Herrschaft im Altertum, Berlin/Boston, 485-508.

Leppin, H. (2020), „George Pisides' Expeditio Persica and Discourses on Warfare in Late Antiquity“, in: A. Lefteratou / F. Hadjittofi (Hgg.), The Genres of Late Antique Christian Poetry: Between Modulations and Transpositions, Berlin/Boston, 293-310.

Lilie, R.-J. (1976), Die byzantinische Reaktion auf die Ausbreitung der Araber: Studien zur Strukturwandlung des byzantinischen Staates im 7. und 8. Jhd., München.

Lilie, R.-J. (1989), „Die Krönungsprotokolle des Zeremonienbuches und die Krönung Kaiser Leons I.“, in: Ch.-F. Collatz (Hg.), Dissertatiunculae criticae. Festschrift für Günther Christian Hansen, Würzburg, 395-408.

Ludwig, C. (1991), „Kaiser Herakleios, Georgios Pisides und die Perserkreige“, Poikilia Byzantina 11, Varia 3, Bonn, 73-128. 
Ludwig, C. (2003), „David - Christus - Basileus. Erwartungen an eine Herrschergestalt“, in: W. Dietrich / H. Herkommer (Hgg.), König David - biblische Schlüsselfigur und europäische Leitgestalt, Fribourg, 367-382.

MacCormack, S. (1972), „Change and Continuity in Late Antiquity: The Ceremony of Adventus“, Historia 21/4, 721-752.

MacCormack, S. (1981), Art and Ceremony in Late Antiquity, Berkeley u. a.

MacCoull, L. S. B. (1998), „George of Pisidia, Against Severus: in Praise of Heraclius“, in: R. Dahood (Hg.), The Future of the Middle Ages and the Renaissance, Turnhout, 69-79.

Macrides, R. / Magdalino, P. (1988), „The Architecture of Ekphrasis: Construction and Context of Paul the Silentiary's Poem on Hagia Sophia“, Byzantine and Modern Greek Studies 12, 47-82.

Magdalino, P. (1994), New Constantines. The Rhythm of Imperial Renewal in Byzantium, $4^{\text {th }}-13^{\text {th }}$ Centuries, Aldershot.

Magdalino, P. (2007), „The History of the Future and its Uses: Prophecy, Policy, and Propaganda“, in: J. Shepard (Hg.), The Expansion of Orthodox Europe. Byzantium, the Balkans and Russia, Aldershot, 29-64,

Magdalino, P. / Nelson, R. S. (2010), The Old Testament in Byzantium, Washington DC.

Maier, F. K. (2019), Palastrevolution. Der Weg zum hauptstädtischen Kaisertum im Römischen Reich des vierten Jahrhunderts, Paderborn.

Makk, F. (1975), Traduction et commentaire de l'homélie écrite probablement par Théodore le Syncelle sur le siège de Constantinople en 626, Szeged.

Malone, Ch. (2009), „Violence on Roman Imperial Coinage“, in: Journal of the Numismatic Association of Australia 20, 58-72.

Mango, C. (1980), Byzantium: The Empire of New Rome, London.

Mango, C. (1984), „A Byzantine Hagiographer at Work: Leontios of Neapolis“, in: I. Hutter (Hg.), Byzanz und der Westen - Studien zur Kunst des europäischen Mittelalters, Wien, 25-41.

Mango, C. (1985), „Deux études sur Byzance et la Perse sassanide“, Travaux et Mémoires du Centre de recherche d'Histoire et Civilisation de Byzance 9, 105-118.

Mango, C. (1990), Nikephoros Patriarch of Constantinople. Short History, Washington DC.

Mango, C. (1992), „The Temple Mount AD 614-638“, in: J. Raby / J. Johns (Hgg.), Bayt Al-Maqdis: Jerusalem and Early Islam, Oxford, 1-16.

Mango, C. (1998), „The Origins of the Blachernae Shrine at Constantinople“, in: Acta XIII Congressus Internationalis Archaeologiae Christianae II, Studi di antichità cristiana 54, Vatican/Split, 61-76.

Mango, C. (2000), „Constantinople as Theotokoupolis“, in: M. Vassilaki (Hg.), The Mother of God: Representations of the Virgin in Byzantine Art, Mailand, 17-25.

Mango, C. / Scott, R. (1997), The Chronicle of Theophanes Confessor: Byzantine and Near Eastern History $A D$ 284-813, Oxford.

Maranci, C. (2008/2009), „The Humble Heraclius. Revisiting the North Portal at Mren“, in: Revue des études arméniennes 31, 167-180.

Mariev, S. (2008), Ioannis Antiocheni fragment aquae supersunt omnia, Berlin/Boston 2008.

Martin, J. (1984), „Zum Selbstverständnis, zur Repräsentation und Macht des Kaisers in der Spätantike“, Saeculum 35, 115-131.

Martin, J. (1997), „Das Kaisertum in der Spätantike“, in: F. Paschoud / J. Szidat (Hgg.), Usurpationen in der Spätantike, Stuttgart, 47-62.

Martschukat, J. / Patzold, S. (2003), Geschichtswissenschaft und „performative turn“. Ritual, Inszenierung und Performanz vom Mittelalter bis zur Neuzeit, Köln u. a.

Mateos, J. (1962), Le Typicon de la grande église, Bd. 1, Rom.

McCormick, M. (1986), Eternal Victory: Triumphal Rulership in Late Antiquity, Byzantium, and the Early Medieval West, Cambridge.

McEvoy, M. (2013), Child Emperor Rule in the Late Roman West, AD 367-455, Oxford. 
McKelvey, R. J. (1969), The New Temple. The Church in the New Testament, Oxford.

Meier, M. (1998), „Exarchat“, Der Neue Pauly 4, $331 \mathrm{f}$.

Meier, M. (2002), „Das Ende des Konsulats im Jahr 541/42 und seine Gründe. Kritische Anmerkungen zur Vorstellung eines ,Zeitalters Justinians'“, Zeitschrift für Papyrologie und Epigraphik 138, 277-299.

Meier, M. (2003a), Das andere Zeitalter Justinians. Kontingenzerfahrung und Kontingenzbewältigung im 6. Jahrhundert n. Chr., Göttingen.

Meier, M. (2003b), „Die Inszenierung einer Katastrophe: Justinian und der Nika-Aufstand“, Zeitschrift für Papyrologie und Epigraphik 142, 273-300.

Meier, M. (2003c), „Göttlicher Kaiser und christlicher Herrscher? Die christlichen Kaiser der Spätantike und ihre Stellung zu Gott“, Das Altertum 48, 129-160.

Meier, M. (2007a), „Staurotheis di’ hemas. Der Aufstand gegen Anastasios im Jahr 512“, Millennium-Jahrbuch 4, 157-238.

Meier, M. (2007b), „Die Demut des Kaisers. Aspekte der religiösen Selbstinszenierung bei Theodosius II. (408-450 n. Chr.)“, in: A. Peçar / K. Trampedach (Hrgg.), Die Bibel als politisches Argument. Voraussetzungen und Folgen, München, 135-158.

Meier, M. (2008), „Aristokratie(n) in Byzanz. Ein Überblick“, in: H. Beck (Hg.), Die Macht der Wenigen. Aristokratische Herrschaftspraxis, Kommunikation und ein „edler“ Lebensstil in Antike und früher Neuzeit, München, 277-300.

Meier, M. (2009a), „Der Christliche Kaiser zieht (nicht) in den Krieg: ,Religionskriege“ in der Spätantike?“, in: A. Holzem (Hg.), Krieg und Christentum. Religiöse Gewalttheorie in der Kriegserfahrung des Westens, Paderborn, 254-278.

Meier, M. (2009b), Anastasios I.: Die Entstehung des Byzantinischen Reiches, Stuttgart.

Meier, M. (2010), „Ariadne - Der ,Rote Faden“ des Kaisertums“, in: A. Kolb (Hg.), Augustae. Machtbewusste Frauen am römischen Kaiserhof?, Berlin, 277-292.

Meier, M. (2012), „Ostrom-Byzanz, Spätantike-Mittelalter. Überlegungen zum ,Ende‘ der Antike im Osten des Römischen Reiches“, Millennium 9, 187-254.

Meier, M. (2014a), „Flavios Hypatios: Der Mann, der Kaiser sein wollte“, in: S. Patzold / K. Ubl (Hgg.), Verwandtschaft, Name und soziale Ordnung (300-1000), Berlin, 73-96.

Meier, M. (2014b), „Kaiser Phokas (602-610) als Erinnerungsproblem“, Byzantinische Zeitschrift $107 / 1,139-174$.

Meier, M. (2015), „Herakles - Herakleios - Christus. Georgios Pisides und der kosmorhýstes“, in: H. Leppin (Hg.), Antike Mythologie in christlichen Kontexten der Spätantike, Berlin, 297-340.

Meier, M. (2016), „Liturgisierung und Hypersakralisierung. Zum Bedeutungsverlust kaiserlicher Frömmigkeit in Konstantinopel zwischen dem 6. und 7. Jahrhundert n. Chr.", in: N. Schmidt / A. Neuwirth / N. K. Schmid (Hgg.), Denkraum Spätantike. Reflexionen von Antiken im Umfeld des Koran, Wiesbaden, 75-106.

Meier, M. (2017), „Der Monarch auf der Suche nach seinem Platz. Kaiserherrschaft im frühen Byzanz (5. bis 7. Jahrhundendert n. Chr.)“, in: S. Rebenich (Hg.), Monarchische Herrschaft im Altertum, Berlin/Boston, 509-544.

Meier, M. (2019a), Geschiche der Völkerwanderung. Europa, Asien und Afrika vom 3. bis zum 8. Jahrhundert $n$. Chr., München.

Meier, M. (2019b), „Der ,Triumph Belisars‘ 534 n. Chr.“, in: R. Conrad / V. H. Drecoll / S. Hirbodian (Hgg.), Säkulare Prozessionen. Zur religiösen Grundierung von Umzügen, Einzügen und Aufmärschen, Tübingen, 43-61.

Meier, M. (2020), „The Roman Context of Early Islam“, Millennium-Jahrbuch 17.1, 265-302.

Menze, v. (2008), Justinian and the Making of the Syrian Orthodox Church, Oxford u.a.

Meyendorff, J. (1989), Imperial Unity and Christian Divisions: The Church 450-680 A.D., Crestwood, NY.

Mitterauer, M. (1991), „Christianity and Endogamy“, Continuity and Change 6/3, 295-333. 
Moffat, A. / Tall, M. (2012), Constantine Porphyrogennetos, the Book of Ceremonies. With the Greek edition of the Corpus Scriptorum Historiae Byzantinae (Bonn, 1892), 2 Bde., Canberra.

Moorhead, J. (1981), „The Monophysite Response to the Arab Invasions“, Byzantion 51, 579-591.

Morrisson, C. (2001), „Du consul a l'empereur: Les sceaux d'Heraclius“, in: C. Sode / S. Takács

(Hgg.), Novum Millennium: Studies on Byzantine History and Culture Dedicated to Paul Speck, Aldershot, 257-266.

Müller-Wiener, W. (1994), Die Häfen von Byzantion, Konstantinupolis, Istanbul, Tübingen.

Mundell-Mango, M. (1994), Imperial Art in the Seventh Century, Aldershot.

Nöldeke, Th. (1893), „Die von Guide herausgegebene syrische Chronik“, Sitzungsberichte der philosophisch-historischen Classe der kaiserlichen Akademie der Wissenschaften 128, 1- 48.

O’Flynn, J. M. (1983), Generalissimos of the Western Roman Empire, Edmonton, Alb.

Oikonomides, N. (1971), „Correspondence between Heraclius and Kavadh-Široe in the Paschale Chronicle (628)“, Byzantion 41, 269-281.

Oikonomides, N. (1975), „A Chronological Note on the First Persian Campaign of Heraclius (622)“, Byzantine and Modern Greek Studies 1, 1-9.

Olajos, T. (1981), „Contributions à une analyse de la genèse de l'Histoire Universelle de Théophylacte Simocatta“, Acta antiqua Academiae Scientiarum Hungaricae 29, 417-424.

Olster, D. M. (1982), „The Dynastic Iconography of Heraclius’ Early Coinage“, Jahrbuch der österreichischen Byzantinistik 32, 399-408.

Olster, D. M. (1985), „Chalcedonian and Monophysite: The Union of 616“, Bulletin de la Société d'Archeologie Copte 27, 93-108.

Olster, D. M. (1991), „The Date of George of Pisidia's 'Hexaemeron'“, Dumbarton Oaks Papers 45, $159-172$.

Olster, D. M. (1993), The Politics of Usurpation in the Seventh Century: Rhetoric and Revolution in Byzantium, Amsterdam.

Olster, D. M. (1994), Roman Defeat, Christian Response, and the Literary Construction of the Jew, Philadelphia.

Omissi, A. (2018), Emperors and Usurpers in the Later Roman Empire: Civil War, Panegyric, and the Construction of Legitimacy, Oxford.

O’Roark, D. A. (1996), „Close-kin Marriage in Late Antiquity: The Evidence of Chrysostom“, Greek, Roman and Byzantine Studies 37, 399-411.

Ortenberg West-Harling, V. (2016), „The Church of Ravenna, Constantinople and Rome in the Seventh Century“, in: J. Herrin / J. L. Nelson (Hgg.), Ravenna: Its Role in Earlier Medieval Change and Exchange, London, 199-210.

Ostrogorsky, G. (1963), Byzantinisches Handbuch, Bd. Teil 1, Bd. 2: Geschichte des byzantinischen Staates, 3. Aufl., München.

Ousterhout, R. (1990), „The Temple, the Sepulchre, and the Martyrion of the Savior“, Gesta 29/1, $44-53$.

Palmer, A. (1993), The Seventh Century in the West-Syrian Chronicles, Liverpool.

Parnell, D. A. (2012), „The Careers of Justinian's Generals“, The Journal of Medieval Military History 10, 1-16.

Parnell, D. A. (2017), Justinian's Men: Careers and Relationships of Byzantine Army Officers, 518-610, London.

Paul, N. L. (2012), To Follow in Their Footsteps: The Crusades and Family Memory in the High Middle Ages, Ithaka, NY u. a.

Payne, R. (2015), A State of Mixture. Christians, Zoroastrians, and Iranian Political Culture in Late Antiquity, Oakland.

Peltomaa, L. M. (2001), The Image of the Virgin Mary in the Akathistos Hymn, Leiden.

Peltomaa, L. M. (2009), „The Role of the Virgin Mary at the Siege of Constantinople in 626“, Scrinium. Journal of Patrology and Critical Hagiography 5/1, 284-299. 
Peltomaa, L. M. (2011), „Epithets of the Theotokos in the Akathistos Hymn“, in: L. Brubaker / M. B. Cunningham (Hgg.), The Cult of the Mother of God in Byzantium. Texts and Images, Farnham u. a., 109-116.

Penna, V. / Morrisson C. (2013), „Usurpers and Rebels in Byzantium: Image and Message Through Coins“, in: D. G. Angelov (Hg.), Power and Subversion in Byzantium, Farnham u. a., 21-42.

Pentcheva, B. V. (2002), „The Supernatural Protector of Constantinople: The Virgin and her Icons in the Tradition of the Avar Siege“, Byzantine and Modern Greek Studies 26, 2- 41.

Pentcheva, B. V. (2006), Icons and Power: The Mother of God in Byzantium, University Park, PA.

Pernice, A. (1905), L'Imperatore Eraclio, Florenz.

Pertusi, G. (1959), Georgius Pisida, Poemi, Bd. 1: Panegirici epici, Ettal.

Peters, F. E. (1983), „Who Built the Dome of the Rock?“, Graeco-Arabica 2, 119-138.

Petit, L. (1904), „Office inédit en l'honneur de Nicéphore Phocas“, Byzantinische Zeitschrift 13/2, $398-420$.

Pfeilschifter, R. (2012), „Die Unmöglichkeit des Machtverlusts. Kontinuität und Ohnmacht der spätantiken Hofeliten“, in: M. Meißner / K. Nebelin / M. Nebelin (Hgg.), Eliten nach dem Machtverlust? Fallstudien zur Transformation von Eliten in Krisenzeiten, Berlin, 133-146.

Pfeilschifter, R. (2013), Der Kaiser und Konstantinopel. Kommunikation und Konfliktaustrag in einer spätantiken Metropole, Berlin.

Pfeilschifter, R. (2014), „Drinnen und Draußen. Die Herrschaft des Kaisers über Konstantinopel und das Reich“, in: M. Meier (Hg.), Chlodwigs Welt. Organisation von Herrschaft um 500, Stuttgart, $111-142$.

Pfeilschifter, R. (2016), „Der Römische Triumph und das Christentum. Überlegungen zur Eigenart eines öffentlichen Rituals“, in: J. Wienand / F. Goldbeck (Hgg.), Der Römische Triumph in Prinzipat und Spätantike, Berlin/Boston, 1-32.

Podskalsky, G. (1972), Byzantinische Reichseschatologie: die Periodisierung der Weltgeschichte in den vier Grossreichen (Daniel 2 und 7) und dem Tausendjährigen Friedensreiche (Apok. 20); eine motivgeschichtliche Untersuchung, München.

Poguntke, A. (2014), „Handlungsspielräume (ost-)römischer Heermeister um 500“, in: M. Meier (Hg.), Chlodwigs Welt. Organisation von Herrschaft um 500, Stuttgart, 397-422.

Poguntke, A. (2016), „Das römische Heermeisteramt im 5. Jahrhundert. Überlegungen zum Verhältnis zwischen Kaiser und Heermeister in Ost und West“, in: C. Föller / F. Schulz (Hr.), Osten und Westen 400-600 n. Chr. Kommunikation, Kooperation und Konflikt, Stuttgart, $239-263$.

Pohl, W. (2002), Die Awaren: ein Steppenvolk in Mitteleuropa 567-822 n. Chr., 2. Aufl., München.

Prigent, V. (2010), „La Sicile de Constant II: l'apport des sources sigillographiques“, in: A. Nef /

V. Prigent (Hgg.), La Sicile de Byzance à l'Islam, 2010, 157-188.

Prinzig, G. (1988), „Beobachtungen zu ,integrierten“ Fürstenspiegeln der Byzantiner“, Jahrbuch der österreichischen Byzantinistik 38, 1-32.

Raby, J. / Johns, J. (1992), Bayt Al-Maqdis: Jerusalem and Early Islam, Oxford.

Rapp, C. (2004), „All in the Family: John the Almsgiver, Nicetas and Heraclius“, Nea Rhome 11, 21-134.

Rapp, C. (2010), „Old Testament Models for Emperors in Early Byzantium“, in: P. Magdalino /

R. Nelson (Hgg.), The Old Testament in Byzantium, Washington, DC, 175-197.

Raum, Th. (2019), „The Reinvention of the Soldier Emperor under Heraclius“, in: M. Kinloch /

A. MacFarlane (Hgg.), Trends and Turning Points. Constructing the Late Antique and Byzantine

World, Leiden/Boston 2019, 133-147.

Ravegnani, G. (2011), Gli esarchi d'Italia, Rom.

Reckwitz, A. (1997) Struktur. Zur sozialwissenschaftlichen Analyse von Regeln und Regelmäßigkeiten, Opladen. 
Redies, M. (1997), „Die Usurpation des Basiliskos (475-476) im Kontext der aufsteigenden monophysitischen Kirche“, Antiquité tardive 5, 211-221.

Reeves, J. C. (2006), Trajectories in Near Eastern Apocalyptic: A Postrabbinic Jewish Apocalypse Reader, Atlanta.

Regan, G. (2003), First Crusader: Byzantiums Holy Wars, New York u.a.

Reich, R. (1993), „The Cemetery in the Mamilla Area of Jerusalem“, Qadmoniot 26, 103-109.

Reinink, G. J. (1983), Das Syrische Alexanderlied, Leuven.

Reinink, G. J. (1985), „Die Entstehung der syrischen Alexanderlegende als politisch-religiöser Propagandaschrift für Herakleios' Kirchenpolitik“, in: C. Laga (Hg.), After Chalcedon. Studies in Theology and Church History Offered to Professor Albert van Roey, Leuven, 263-281.

Reinink, G. J. (1988), „Pseudo-Methodius und die Legende vom römischen Endkaiser“, in: W. Verbeke / D. Verhelst / A. Welkenhuysen (Hgg.), The Use and Abuse of Eschatology in the Middle Ages, Leuven, 82-111.

Reinink, G. J. (1993), Die Syrische Apokalypse des Pseudo-Methodius, Leuven.

Reinink, G. J. (2002), „Heraclius, the New Alexander. Apocalyptic Prophecies during the Reign of Heraclius“, in: ders. / B. Stolte (Hgg.), The Reign of Heraclius (610-641). Crisis and Confrontation, Leuven, 81-94.

Reinink, G. J. / Stolte, B. (2002), The Reign of Heraclius (610-641). Crisis and Confrontation, Leuven.

Roberto, U. (2005), Ioannis Antiocheni fragementa ex historia chronica, Berlin.

Roberto, U. (2010), „The Circus Factions and the Death of the Tyrant: John of Antioch on the Fate of the Emperor Phocas“, in: F. Daim / J. Drauschke (Hgg.), Byzanz - Das Römerreich im Mittelalter, Bd. 1: Welt der Ideen, Welt der Dinge, Mainz, 55-77.

Rösch, G. (1978), Onoma Basileias: Studien zum offiziellen Gebrauch der Kaisertitel in spätantiker und frühbyzantinischer Zeit, Wien.

Rösch, G. (1979), „Der Aufstand der Herakleioi gegen Phokas (608-610) im Spiegel numismatischer Quellen“, Jahrbuch der österreichischen Byzantinistik 2, 851-862.

Rubin, Z. (2004), „Nobility, Monarchy and Legitimation under the Later Sasanians“, in: J. F. Haldon / L. I. Conrad (Hgg.), The Byzantine and Early Islamic Near East, Princeton NJ., $235-274$.

Sarris, P. (2011), Empires of Faith. The Fall of Rome to the Rise of Islam, 500-700, Oxford.

Scher, A. (1908-1919), Histoire nestorienne inédite: Chronique de Séert, Paris.

Schilling, A. M. (2008), Die Anbetung der Magier und die Taufe der Sāsāniden: zur Geistesgeschichte des iranischen Christentums in der Spätantike, Leuven.

Schmitt, O. J. (1994), „Die Buccellarii. Eine Studie zum militärischen Gefolgschaftswesen in der Spätantike“, Tyche 9, 147-174.

Schneider, P. (1985), Theophylaktos Simokates, Geschichte, Stuttgart.

Schneider, P. (1989), „Eine chinesische Beschreibung Konstantinopels aus dem 7. Jahrhundert“, Istanbuler Mitteilungen 39, 493-505.

Schönborn, C. (1972), Sophrone de Jérusalem: vie monastique et confession dogmatique, Paris.

Schwarcz, D. (2003), „Marriage and Power Politics in the Fifth Century“, Medieval Prosopography $24,36-45$.

Scott, R. D. (1985), „Malalas, the Secret History, and Justinian’s Propaganda“, Dumbarton Oaks Papers 39, 99-109.

Scott, R. D. (2012), „Justinian's New Age and the Second Coming“, in: ders. (Hg.), Byzantine Chronicles and the Sixth Century, XVIII, 1-22.

Sguaitamatti, L. (2012), Der spätantike Konsulat, Fribourg.

Shahid, I. (1972), „The Iranian Factor in Byzantium during the Reign of Heraclius“, Dumbarton Oaks Papers 26, 293-320. 
Shahid, I. (1980/81), „Heraclius 'pistos en Christo basileus'“, Dumbarton Oaks Papers 34/35, $225-237$.

Shoemaker, S. J. (2008), „The Cult of Fashion: The Earliest 'Life of the Virgin' and Constantinople's Marian Relics“, Dumbarton Oaks Papers 62, 53-74.

Shoemaker, S. J. (2018), The Apocalypse of Empire: Imperial Eschatology in Late Antiquity and Early Islam, Philadelphia.

Siebigs, G. (2010), Kaiser Leo I.: Das oströmische Reich in den ersten drei Jahren seiner Regierung (457-460 n. Chr.), 2 Bde., Berlin u.a.

Simeonov, G. (2016), „Der Hafen und die Anlegestelle des Hebdomon“, in: F. Daim (Hg.), Die byzantinischen Häfen Konstantinopels, Mainz, 121-138.

Sirotenko, A. (2017), „Forgetting the Heretic: The Emperor Heraclius in the Byzantine Liturgical Tradition“, Jahrbuch der österreichischen Byzantinistik 67, 239-248.

Sirotenko, A. (2018), „Constructing Memory the Chronicle of Theophanes on the Reign of Heraclius“, in: Ch. Messis / M. Mullett / I. Nilsson (Hgg.), Storytelling in Byzantium. Narratological Approaches to Byzantine Texts and Images, Uppsala, 223-242.

Sivan, H. S. (2000), „From Byzantine to Persian Jerusalem: Jewish Perspectives and Jewish/Christian Polemics“, Greek, Roman and Byzantine Studies 41, 277-306.

Sivan, H. S. (2008), Palestine in Late Antiquity, Oxford u. a.

Sode, C. (2009), „Die Krönung des Kaisers Justin I. im Zeremonienbuch Konstantins VII. Porphyrogennetos“, Mediterraneo antico 12, 429-448.

Sommerlechner, A. (2003), „Kaiser Herakleios und die Rückkehr des Heiligen Kreuzes nach Jerusalem. Überlegungen zu Stoff- und Motivgeschichte“, in: Römische Historische Mitteilungen 45, 319-360.

Spain Alexander, S. (1977), „Heraclius, Byzantine Imperial Ideology, and the David Plates“, Speculum 52/2, 217-237.

Spanos A. Ph. / Zarras N. (2009), „Representations of Emperors as Saints in Byzantine Textual and Visual Sources“, in: M. Borgolte / B. Schneidmüller (Hgg.), Hybride Kulturen im mittelalterlichen Europa, Berlin, 63-78.

Speck, P. (1980), Zufälliges zum Bellum Avaricum des Georgios Pisides, München.

Speck, P. (1981), Artabasdos, der rechtgläubige Vorkämpfer der göttlichen Lehren: Untersuchungen zur Revolte des Artabasdos und ihrer Darstellung in der byzantinischen Historiographie, Bonn.

Speck, P. (1988), Das geteilte Dossier: Beobachtungen zu den Nachrichten über die Regierung des Kaisers Herakleios und der seiner Söhne bei Theophanes und Nikephoros, Bonn.

Speck, P. (1993), „Eine Gedächtnisfeier am Grabe des Maurikios. Die Historiae des Theophylaktos Simokates: der Auftrag; die Fertigstellung; der Grundgedanke“, Varia 4, Poikila byzantina 12, $175-254$

Speck, P. (1997a), „Epiphania et Martine sur les monnaies d'Héraclius“, Revue numismatique 152, 457-465.

Speck, P. (1997b), „Beiträge zum Thema byzantinische Feindseligkeit gegen die Juden im frühen siebten Jahrhundert nebst einer Untersuchung zu Anastasios dem Perser“, Varia 6, Poikila byzantina 15, Bonn.

Speck, P. (1998), „Ohne Anfang und Ende: Das ,Hexaemeron“ des Georgios Pisides“, in:

I. Ševcenko / I. Hutter (Hgg.), Aetos. Studies in honour of Cyril Mango, Stuttgart u.a., $314-328$.

Speck, P. (2000), „Zum Datum der Translation der Kreuzreliquien nach Konstantinopel“, Varia 7, Poikila Byzantina 18, 167-177.

Speck, P. (2003), „The Virgin’s Help for Constantinople“, Byzantine and Modern Greek Studies 27, $266-271$.

Speigl, J. (1995), „Formula lustiniani. Kircheneinigung mit kaiserlichen Glaubensbekenntnissen (Codex lustinianus I, 1, 5-8)“, Ostkirchliche Studien 44, 105-134. 
Stäcker, J. (2003), Princeps und miles: Studien zum Bindungs- und Nahverhältnis von Kaiser und Soldat im 1. und 2. Jahrhundert n. Chr., Hildesheim u. a.

Stein-Hölkeskamp, E., „Zwischen Parodie und Perversion. Verkehrungen des Triumphs in der frühen Kaiserzeit“, in: D. Boschung / K.-J. Hölkeskamp / C. Sode (Hgg.), Raum und Performanz. Rituale in Residenzen von der Antike bis 1815, Stuttgart, 127-142.

Steinicke, M. (2005), „Politische und artistische Zeichensetzung. Zur Dynamik von Krönungs- und Investiturritualen“, in: dies. / S. Weinfurter (Hgg.), Investitur- und Krönungsrituale. Herrschaftseinsetzungen im kulturellen Vergleich, Köln u.a., 1-26.

Sternbach, L. (1891), „Georgii Pisidae carmina inedita“, Wiener Studien. Zeitschrift für classische Philologie 13, 1-62.

Sternbach, L. (1892), „Georgii Pisidae Carmina inedita, pars II“, Wiener Studien. Zeitschrift für classische Philologie 14 (1892) 51-68.

Stewart, M. E. (2016), The Soldiers's Life: Martial Virtues and Manly Romanitas in the Early Byzantine Empire, Leeds.

Stoll, O. (2016), „Vae Victis? Das kaiserzeitliche Rom und sein Umgang mit Niederlage“, in: ders. / L. Meier (Hgg.), Niederlagen und Kriegsfolgen - Vae Victis oder Vae Victoribus?, Berlin, 1-10.

Stouraitis, I. (2012), ,Just War and Holy War in the Middle Ages. Rethinking Theory through the Byzantine Case-Study“, Jahrbuch der Österreichischen Byzantinistik 62, 227-264.

Stoyanov J. P. (2011a), Defenders and Enemies of the True Cross: the Sasanian Conquest of Jerusalem in 614 and Byzantine Ideology of Anti-Persian Warfare, Wien.

Stoyanov J. P. (2011b), „Archaeology versus Written Sources: The Case of the Persian Conquest of Jerusalem in 614", Terra antiqua Balcanica et mediterranea 1, 351-358.

Stratos, A. N. (1968), Byzantium in the Seventh Century, Bd. 1: 602-634, Amsterdam.

Stratos, A. N. (1972), Byzantium in the Seventh Century, Bd. 2: 634-641, Amsterdam.

Stratos, A. N. (1975), Byzantium in the Seventh Century, Bd. 3: 642-668, Amsterdam.

Stratos, A. N. (1978), Byzantium in the Seventh Century, Bd. 4: 668-685, Amsterdam.

Stratos, A. N. (1980), Byzantium in the Seventh Century, Bd. 5: Justinian II., Leontius and Tiberius 685-711, Amsterdam.

Stratos, A. N. (1979), „La première campagne de l'Empereur Héraclius contre les Perses“, Jahrbuch der Österreichischen Byzantinistik 28, 63-74.

Suter, A. / Hettling, M. (2001), „Struktur und Ereignis - Wege zu einer Sozialgeschichte des Ereignis“, in: dies. (Hgg.), Struktur und Ereignis, Göttingen, 7-32.

Szidat, J. (1979), „Die Usurpation des Eugenius“, Historia 28, 487-508.

Szidat, J. (1981), „Zur Wirkung und Aufnahme der Münzpropaganda (lul. Misop. 355 d)“, Museum Helveticum 38/1, 22-33.

Szidat, J. (2010), Usurpator tanti nominis: Kaiser und Usurpator in der Spätantike (337-476 n. Chr.), Stuttgart.

Tambiah, S. (2008), „Eine performative Theorie des Rituals“, in: A. Belliger (Hg.), Ritualtheorien. Ein einführendes Handbuch, 4. Aufl., Wiesbaden, 223-246.

Tannous, J. (2014), „In Search of Monotheletism“, Dumbarton Oaks Papers 68, $29-67$.

Tartaglia, L. (1998), Carmi di Giorgio di Pisidia, Torino.

Thierry, M. / Thierry, N. (1971), „La cathédrale de Mrèn et sa decoration“, Cahiers archéologiques. Fin de l'antiquité et moyen-âge 21, 43-77.

Thierry, N. (1997), „Héraclius et la Vraie Croix en Arménie“, in: J.-P. Mahé / R. W. Thomson (Hgg.), From Byzantium to Iran. In Honour of Nina Garsoïan, Atlanta, 165-186.

Thomson, R. W. / Howard-Johnston, J. (1999), The Armenian History attributed to Sebeos, 2 Bde., Liverpool.

Tinnefeld, F. H. (1971), Kategorien der Kaiserkritik in der byzantinischen Historiographie: von Prokop bis Niketas Choniates, München. 
Trampedach, K. (2001), „Die Konstruktion des Heiligen Landes. Kaiser und Kirche in Palaestina von Constantin bis Justinian“, in: M. Sommer / I. Geiss / M. Heinz (Hgg.), Die Levante: Beiträge zur Historisierung des Nahostkonflikts, Freiburg i. Br., 83-110.

Trampedach, K. (2005), „Kaiserwechsel und Krönungsritual im Konstantinopel des 5. -6. Jahrhunderts“, in: M. Steinicke / S. Weinfurter (Hgg.), Investitur- und Krönungsrituale. Herrschaftseinsetzungen im kulturellen Vergleich, Köln u. a., 275-290.

Trampedach, K. (2015), „Ein neuer Tempel Salomons in Jerusalem? Der Bau der Nea-Kirche (531-543) durch Kaiser Justinian“, Millenium-Jahrbuch 12, 155-178.

Trampedach, K. (im Druck), „The Making of the Holy Land in Late Antiquity“, in: K. Klein / J. Wienand (Hgg.), City of Caesar, City of God: Constantinople and Jerusalem in Late Antiquity. Trampedach, K. (im Druck), „A New Temple of Solomon in Jerusalem? The Construction of the Nea Church (531-543) by Emperor Justinian“, in: K. Klein / J. Wienand (Hgg.), City of Caesar, City of God: Constantinople and Jerusalem in Late Antiquity.

Treadgold, W. T. (1997), A History of the Byzantine State and Society, Stanford, CA.

Treadgold, W. T. (2007), The Early Byzantine Historians, Basingstoke u. a.

Treitinger, O. (1938), Die oströmische Kaiser- und Reichsidee nach ihrer Gestaltung im höfischen Zeremoniell, Jena.

Trilling, J. (1978), „Myth and Metaphor at the Byzantine Court. A Literary Approach to the David Plates“, Byzantion 48, 249-263.

Trypanis, C. A. (1968), Fourteen Early Byzantine Cantica, Wien.

Tsamakda, V. (2010), „König David als Typos des byzantinischen Kaisers“, in: F. Daim / J. Drauschke (Hgg.), Byzanz - Das Römerreich im Mittelalter, Bd. 1: Welt der Ideen, Welt der Dinge, Mainz, $23-54$.

Turtledove, H. N. (1983), „Justin Il’s Observance of Justinian’s Persian Treaty of 562“, Byzantinische Zeitschrift 76, 292-301.

Uthemann, K.-H. (1999), „Kaiser Justinian als Kirchenpolitiker und Theologe“, Augustinianum 39, $5-84$.

Van Bekkum, W. J. (2002), „Jewish Messianic Expectations in the Age of Heraclius“, in: G. J. Reinink / B. Stolte (Hgg.), The Reign of Heraclius (610-641). Crisis and Confrontation, Leuven, 95-112.

Van Dieten, J. L. (1972), Geschichte der Patriarchen von Sergios I. bis Johannes VI. (610-715), Amsterdam.

Van Dieten, J. L. (1985), „Zum ,Bellum Avaricum‘ des Georgios Pisides. Bemerkungen zu einer Studie von Paul Speck“, Byzantinische Forschungen 9, 149-178.

Van Donzel, E. J. / Schmidt, A. (2010), Gog and Magog in Early Eastern Christian and Islamic Sources: Sallams Quest for Alexanders Wall, Leiden u.a.

Van Esbroeck, M. (1976), „Une chronique de Maurice à Héraclius dans un récit des sièges de Constantinople“, Bedi Kartlisa 34, 74-96.

Van Ginkel, J. J. (2002), „Heraclius and the Saints. The 'Popular' Image of an Emperor“, in: G. J. Reinink / B. Stolte (Hgg.), The Reign of Heraclius (610-641). Crisis and Confrontation, Leuven, 226-240.

Viermann, N. (im Druck), „Surpassing Solomon. Church-building and Political Communication in Constantinople“, in: K. Klein / J. Wienand (Hgg.), City of Caesar, City of God: Constantinople and Jerusalem in Late Antiquity.

Vivian, T. / Athanassakis, A. N. (1994), The Life of St. George of Choziba and the Miracles of the Most Holy Mother of God at Choziba, San Francisco.

Wallace-Hadrill, J. M. (1960), The Fourth Book of the Chronicle of Fredegar with its Continuations, London.

Wander, S. H. (1973), „The Cyprus Plates: The Story of David and Goliath“, Metropolitan Museum Journal 8, 89-104. 
Wander, S. H. (1975), „The Cyprus Plates and the 'Chronicle’ of Fredegar“, Dumbarton Oaks Papers $29,345 \mathrm{f}$.

Wassiliou-Seibt, A.-K. (2017), „From magister militum to strategos: the Evolution of the Highest Military Commands in Early Byzantium $\left(5^{\text {th }}-7^{\text {th }} \text { c.) }\right)^{\text {c }}$, in: B. Caseau / V. Prigent / A. Sopracasa

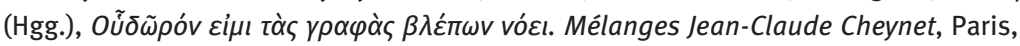
$789-802$.

Watt, J. W. (2002), „The Portrayal of Heraclius in Syriac Historical Sources“, in: G. J. Reinink / B. Stolte (Hgg.), The Reign of Heraclius (610-641). Crisis and Confrontation, Leuven, 63-80.

Wellesz, E. (1956), „The 'Akathistos.' A Study in Byzantine Hymnography“, Dumbarton Oaks Papers 9/10, $141-174$.

Welskopp, Th. (2001), „Die Dualität von Struktur und Handeln. Anthony Giddens' Strukturierungstheorie als ,praxeologischer" Ansatz in der Geschichtswissenschaft“, in: A. Suter / M. Hettling (Hgg.), Struktur und Ereignis, Göttingen, 99-119.

Wenger, A. (1955), L'assomption de la T. S. vierge dans la tradition byzantine du Vle au Xe siècle: études et documents, Paris.

Whately, C. (2013), „Militarization, or the Rise of a Distinct Military Culture? The East Roman Ruling Elite in the $6^{\text {th }}$ Century AD“, in: S. O'Brien / D. Boatright (Hgg.), Warfare and Society in the Ancient Eastern Mediterranean, Oxford, 49-57.

Wheeler, B. M. (1991), „Imagining the Sasanian Capture of Jerusalem. The 'Prophecy and Dream of Zerubbabel' and Antiochus Strategos' 'Capture of Jerusalem'“, Orientalia christiana periodica $57,69-85$.

Whitby, Ma. (1985), „The occasion of Paul the Silentiary’s Ekphrasis of S. Sophia“, The Classical Quarterly 35, 215-228.

Whitby, Ma. (1987), „On the Omission of a Ceremony in Mid-Sixth Century Constantinople: Candidati, Curopalatus, Silentiarii, Excubitores and Others“, Historia 36, 462-488.

Whitby, Ma. (1994), „A New Image for a New Age: George of Pisidia on the Emperor Heraclius“, in: E. Dąbrowa (Hg.), The Roman and Byzantine Army in the East, Krakau, 197-225.

Whitby, Ma. (1995), „The Devil in Disguise: The End of George of Pisidia's Hexaemeron Reconsidered“, The Journal of Hellenic Studies 115, 115-129.

Whitby, Ma. (1998), „Defender of the Cross: George of Pisidia on the Emperor Heraclius and his Deputies“, in: dies. (Hg.), The Propaganda of Power. The Role of Panegyric in Late Antiquity, Leiden u.a., 247-273.

Whitby, Ma. (2002), „George of Pisidias Presentation of the Emperor Heraclius and his Campaigns: Variety and Development“, in: G. J. Reinink / B. Stolte (Hgg.), The Reign of Heraclius (610-641). Crisis and Confrontation, Leuven, 157-174.

Whitby, Ma. (2003), „George of Pisidia and the Persuasive Word: Words, Words, Words...“, in: E. Jeffreys (Hg.), Rhetoric in Byzantium, Ashgate, 173-186.

Whitby, Ma. (2020), „The Patriarch Sergius and the Theotokos“, Jahrbuch der österreichischen Byzantinistik 70.

Whitby, Ma. / Whitby, Mi. (1986), The History of Theophylact Simocatta. An Englisch Translation with Introduction and Notes, Oxford.

Whitby, Ma. / Whitby, Mi. (1989), Chronicon Paschale 284-628 AD, Liverpool.

Whitby, Mi. (1988), The Emperor Maurice and His Historian: Theophylact Simocatta on Persian and Balkan Warfare, Oxford.

Whitby, Mi. (2000a), „The Successors of Justinian“, in: ders. / Av. Cameron / B. Ward-Perkins (Hgg.), The Cambridge Ancient History, Bd. 14: Late Antiquity. Empire and Successors, Cambridge, 86-111.

Whitby, Mi. (2000b), „The Army, c. 420-602“, in: ders. / Av. Cameron / B. Ward-Perkins (Hgg.), The Cambridge Ancient History, Bd. 14: Late Antiquity. Empire and Successors, Cambridge, $288-314$. 
Whitby, Mi. (2000c), The Ecclesiastical History of Evagrius Scholasticus, Liverpool.

Whitby, Mi. (2004), „Emperors and Armies, AD 235-395“, in: S. Swain (Hg.), Approaching Late Antiquity. The Transformation from Early to Late Empire, Oxford, 156-186.

Wickham, Ch. (2005), Framing the Early Middle Ages: Europe and the Mediterranean 400-800, Oxford u.a.

Wienand, J. (2011), „Der blutbefleckte Kaiser. Constantin und die martialische Inszenierung eines prekären Sieges“, in: M. Fahlenbock (Hg.), Inszenierung des Sieges - Sieg der Inszenierung, Innsbruck u. a., 237-254.

Wienand, J. (2012), Der Kaiser als Sieger: Metamorphosen triumphaler Herrschaft unter Constantin I., Berlin.

Wienand, J. (2015a), „The Cloak of Power: Dressing and Undressing the King“, in: ders. (Hg.), Contested Monarchy. Integrating the Roman Empire in the Fourth Century AD, Oxford, 3-14.

Wienand, J. (2015b), „O tandem felix civili, Roma, victoria! Civil-War Triumphs from Honorius to Constantine and back“, in: ders. (Hg.), Contested Monarchy. Integrating the Roman Empire in the Fourth Century AD, Oxford, 169-197.

Wienand, J. (2016a), „The Impaled King: A Head and its Context“, in: ders. / H. Börm / M. Mattheis (Hgg.), Civil War in Ancient Greece and Rome: Contexts of Disintegration and Reintegration, Stuttgart, 417-432.

Wienand, J. (2016b), „Religiöse Toleranz als politisches Argument: Konzeptionelle Überlegungen zur konstantinischen Wende“, in: M. Wallraff (Hg.), Religiöse Toleranz. 1700 Jahre nach dem Edikt von Mailand, Berlin u.a., 67-100.

Wienand J. / Klein, K. (im Druck), City of Caesar, City of God: Constantinople and Jerusalem in Late Antiquity.

Wijnendaele, J. (im Druck), „Irregularly Recruited Soldiers“, in: Ph. Rance (Hg.), Brill Compagnion to Military Culture in Late Antiquity.

Wilken, R. L. (1992), The Land Called Holy: Palestine in Christian History and Thought, New Haven u.a.

Winkelmann, F. / Ditten, H. / Rochow, I. (1978), Byzanz im 7. Jahrhundert. Untersuchungen zur Herausbildung des Feudalismus, Berlin.

Winkelmann, F. (1978), „Zur Rolle der Patriarchen von Konstantinopel bei den Kaiserwechseln in frühbyzantinischer Zeit“, Klio 60, 467-482.

Winkelmann, F. (1987), „Die Quellen zur Erforschung des monoenergetisch-monotheletischen Streites“, Klio 69, 515-559.

Winkelmann, F. (2001), Der monenergetisch-monotheletische Streit, Frankfurt a. M. u. a.

Winterling, A. (2011), „Zu Theorie und Methode einer neuen Römischen Kaisergeschichte“, in: ders. (Hg.), Zwischen Strukturgeschichte und Biographie, Oldenburg, 1-11.

Wood, Ph. (2011), „We Have no King but Christ“: Christian Political Thougth in Greater Syria on the Eve of the Arab Conquest (c. 400-585), Oxford.

Wood, Ph. (2013), The Chronicle of Seert: Christian Historical Imagination in Late Antique Iraq, Oxford.

Woods, D. (2006), „On the Health of the Emperor Heraclius c. 638-641“, Byzantinoslavica 64, 99-110.

Yannopoulos, P. A. (1978), L'hexagramme: un monnayage byzantin en argent du VIle siècle, Louvain-la-Neuve.

Zagros, G. / Veglery, A. (1972), Byzantine Lead Seals, Bd. 1.1, Basel.

Zahnd, U. (2008), „Novus David - Neos David: zur Frage nach byzantinischen Vorläufern eines abendländischen Topos“, Frühmittelalterliche Studien 42, 71-87.

Zocca, E. (1992), „Onorio e Martino: due papi di fronte al monotelismo“, in: Martino I papa (649-653) e il suo tempo, Spoleto, 103-147. 
Zuckerman, C. (1988), „The Reign of Constantine V in the Miracles of St. Theodore the Recruit (BHG 1764)“, Revue des études byzantines 46/1, 191-210.

Zuckerman, C. (1995), „La petite Augusta et le Turc. Epiphania-Eudocie sur les monnaies d'Héraclius“, Revue numismatique 6 (150), 113-126.

Zuckerman, C. (2002), „Heraclius in 625“, Revue des études byzantines 60/1, 189-197.

Zuckerman, C. (2007), „The Khazars and Byzantium - The First Encounter“, in: P. B. Golden / H. Ben-Shammai / A. Róna-Tas (Hgg.), The World of the Khazars. New Perspectives, Leiden u. a., 399-432.

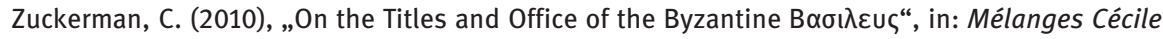
Morrisson, Travaux et Mémoires 16, 865-890.

Zuckerman, C. (2013), „Heraclius and the Return of the Holy Cross“, in: ders. (Hg.), Constructing the Seventh Century, Travaux et Mémoirs 17, Paris, 197-218. 


\subsection{Register}

\subsubsection{Personenregister}

Abu Bakr 300, 303

Agapios 22, 25

Agathias 9,

Alexander der Große 18, 139, 236, 242-248

Alexander (Prätorianerpräfekt) 209

Alkestis 135, 239, 297 Anm. 216

Al-Tabari 25

Anastasia (Tiberios' Ehefrau) 168

Anastasia (Herakleios' Tochter) 311 Anm. 279

Anastasios I. 48f., 51, 54-58, 60-63, 65, $88,92,109,116$,

Anastasios der Perser 13 Anm. 4, 16 f., 201 Anm. 69

Anicia Juliana 54

Anicius Olybrius 54, 63

Anthemios 53, 63

Antiochos Strategos 16, 269, 271

Antonina 99

Ardabur 51

Ardashir 261, 263 Anm. 40, 283

Areobindos 54, 61

Ariadne $\quad 51-55,61$

Arkadios 27, 29, 31, 50 f., $162 \mathrm{f}$., 168

Armatos 52 Anm. 111, 53, 89

Artabanes 57, 61

Aspar 44, 48, 51f., 54f., 60f., 63, 109, 324

Atalarich 207 Anm. 94, 304, 307 f., 318

Athanasios der Kameltreiber 286

Augustina 311 Anm. 279

Baanes 302

Baram Chobin 71-74, 89, 233, 283

Basiliskos 51-53, 78f., 89f., 114, 118, 167

Benjamin 26, 286, 303

Belisar $\quad 42-44$, 47, 57, 64f., 89, 99, 197, 199

Bonifaz 143

Bonos 184, 189-191, 210-212, 214, 218, 224,

Bonosos 95, 102

Boran 283, 286

Caligula 309

Callinicus 134

Charito 59

Chosroes I. $67 \mathrm{f} ., 71$

Chosroes II. 10,12, 17, 19, 71-73, 89f., 134, $140 \mathrm{f} ., 147 \mathrm{f} ., 151,157,164,179-181,206-$

209, 230-233, 237-239, 248, 252-254, 260, 263, 280, 283, 291, 294, 296, 299, 304,340

Constantius II. 37

Constantius Chlorus 50

David (Herakleios' Sohn) 175, 235, 311, 322

David (König) 223f., 274-279, 281, 298f., 337, 344

David (General) 263

David (Logothet) 322

David Saharuni 269 Anm. 66

Dionysios von Tel-Mare 22

Domentzia 99, 148

Domentziolos (Phokas' Bruder) 101, 140

Domentziolos (Phokas' Neffe) 140 f., 144

Eleutherios 179

Epiphania 177 Anm. 188, 155 Anm. 75, 162 f., 184, 207, 229 Anm. 207

Eudokia 102 Anm. 120, 113, 119, 162, $171 \mathrm{f}$., 318,338

Eugenius 163

Euseb von Caesarea 133, 191 Anm. 26, 246, 297

Eutychios (Patriarch) $292 \mathrm{f}$.

Eutychios (Sa'id ibn Batriq) 25

Evagrios Scholastikos 78f., 128

Ezr 286

Flavios $174 \mathrm{f} .$, Anm. 169

Fredegar 22, 245 Anm. 270, 269, Anm. 67, 278, 287, Anm. 163

Gainas 91, 325

Gelimer 125 Anm. 213, 255 Anm. 10

Georg von Antiochia 81

Georg von Pisidien 12-15, 24, 100 f., 131 136, 181, 181-197, 200-205, 213-228, 236, $238-242,249$ f., 253, 256, 259 f., 270 f., 274-282, 293-297, 306, 309, 312, $336 \mathrm{f} ., 343 \mathrm{f}$.

Georg Synkellos 24

Germanos Senior 57-59

Germanos Junior $59 \mathrm{f} ., 71,84 \mathrm{f} ., 87 \mathrm{f} ., 91 \mathrm{f}$., 99, 110, $120 \mathrm{f.,} 146 \mathrm{f.,} 150$

Germanos (Kommandeur von Edessa) 83 
Goliath $275,277 \mathrm{f}$.
Goripp $\quad 66 \mathrm{f}$.
Gratian $\quad 308$
Gregor der Große $142 \mathrm{f}$.
Gregoria $\quad 161,174$
Gregorios $\quad 313 \mathrm{Anm} .282,326 \mathrm{f} ., 329$

Helena $264 \mathrm{f}$.

Herakleios Konstantin 117 Anm. 187f., 119, 155f., 161-166, 172, 174, 178, 184, 187, 190 f., 207 f., 215 f., 220, $224-226,234$ f., 256, 258, 282, 307, 310, 317-320, 329, 338

Herakleios Senior 71, 79, 94-99

Herakles 135f., 200 Anm. 67, 213, 239, 294, 297 Anm. 216

Heraklonas 117 Anm. 186, 188, 166 f., 172

Anm. 156, 175 Anm. 169, 236, 259

Anm. 26, 310-313, 315, 318-325, 338

Honorius 50, 73 Anm. 200

Honorius (Papst) 287, 314

Hormizdas 71

Hypatios $47,55-57,61,90$

Illous $53 \mathrm{f}$.

Ishoyahb 283-286

Jesaja $223 \mathrm{f}$.

Johannes der Almosengeber 19, $161 \mathrm{f}$.

Johannes von Antiochia 11, $148 \mathrm{f}$.

Johannes Lydos 31

Johannes Malalas 11

Johannes von Nikiu 19f., 98, 112, $323 \mathrm{f}$.

Johannes Seismos $209 \mathrm{f}$.

Johannes (Mizizes’ Sohn) 331 Anm. 66

Jovian 50

Julian 54, 68, 78, 107 Anm. 142, 120 Anm. 194, 169

Justin I. $\quad 51,55 \mathrm{f} ., 60,118$

Justin II. $58 \mathrm{f.,} 62 \mathrm{f.}, 66-70,96,145,168$, 173f., 189, 290

Justin (General) 63

Justinian I. $38,40,42-44,47-49,51$, $55-58,61,65-68,89-90,94,96,108 f .$, $118,123,168,198-200,215,241,258$, 260, 265, 273, 289, 292f., 307 Anm. 260, 315,336

Justinian II. $\quad 70,318,331 \mathrm{f}$.

Justinian (General) 70, 307 Anm. 260
Kallinikos 58

Kalliopas 102 Anm. 120

Kavadh Seiroe 12, 181, 203, 231-233, 252254, 257, 260 f., 340

Kedrenos 149

Keler 55

Komentiolos (General) 81, 140

Komentiolos (Phokas' Bruder), 151-153

Komitas 21

Konstans II. 23, 313 Anm. 282, 315, 320331, 338

Konstantin der Große $39,45,50,78 f ., 126$, 167, 170, 190, 191 Anm. 126, 197, Anm. 149, 255, 281-283, 289, 297 Anm. 217

Konstantin IV. 23, 329, 331

Konstantin Lardys 88,140

Konstantin Porphyrogennetos 25

Konstantin (Herakleios' Sohn) $174 \mathrm{f}$., Anm. 169

Konstantina 59, 143 Anm. 23, 146 f., 168

Kosmas 144

Kyriakos $88,110,143$ Anm. 23

Kyros $286-288,303,322$

Leon I. $\quad 31$, Anm. 16, 44, 46, 48, 51-53, 60 f., $63,107-109,114,116,221,324$

Leon II. 51, 108, 114

Leontia (Tochter des Leon I.) 53

Leontia (Phokas' Ehefrau) 111, 142, 148, 168

Leontios (Usurpator unter Zenon) 35 Anm. 29, 53 f., 83, 127

Leontios (Kaiser) $331 \mathrm{f}$.

Leontios von Neapolis 19

Leontios (Sakkelarios) 126

Longinos $48,54,65$

Markian I. 38, 48, 51f., 61, 109 Anm. 150 152, 164 Anm. 112, 289, 297

Markian 53

Markos 51, 167

Martin (Papst) 327

Martina $166,171-175,184,207,266,276$, 278 Anm. 117, 310f., 313, 315, 318-325, $335,338,343,345$

Maurikios $5,10,23,51,59-61,70-77$, 79-94, 97, 99, 101, 103f., 110-112, 114, $116,118,120,122-125,134,139-144$, 146-148, 151f., 154, 156, 162-164, 168, 
181f., 202, 233, 240, 252, 284, 298, 317,

319 Anm. 5, 334

Maxentius 45, 126, 200 Anm. 66

Maximos Confessor 288, 298 Anm. 224, 326, 330 Anm. 57

Melchisedek $298 \mathrm{f}$.

Menander Protektor 10

Menas 144

Michael Syrus 22

Mizizes 331

Modestos 16, 20, 266, 268 Anm. 64

Mohammed 300

Moses 132, 219 Anm. 155, 224

Movses Dasxuranci 21

Mundos 47

Narses (Eunuch) 64, 74

Narses 140-142, $151 \mathrm{f}$.

Nikephoros 23f., 120,154f., 171-173, $180 \mathrm{f}$., 233f., 257-259, 304-306, 308, 310, $314 \mathrm{f.}, 318$

Nikephoros Phokas 203 Anm. 83, 204 Anm. 87

Niketas (Herakleios' Cousin) 95, 98, 155 Anm. 75, 156, 160-162, 174, 182, 291

Niketas (Shahrbaraz' Sohn) 262, 311 Anm. 278

Odoaker 27

Olympios 327,329

Patrikios 52

Paulos Silentiarios 189, 199

Paulos II. (Patriarch) 322, 325

Petros (Maurikios' Bruder) $81-83,111,140$

Philagrios 320

Philippikos 81, 161

Philippikos Bardanes 332, 346

Phineas $132 \mathrm{f}$.

Phokas 5, $10 \mathrm{f} ., 20,44,47,79,83-85,99-$ $105,107,110-116,118,120-153,156 \mathrm{f} .$, $161,164,166,168,182-185,202,238$, 240, 284, 296, 317, 321, $334 \mathrm{f}$.

Pompeios 55-57

Praeiecta 57

Priscian 65

Priskos 44, 47, 81-83, 98-102, 122, $120 \mathrm{f}$., 140, 148, 153-156, $160 \mathrm{f.,} 174$

Probos 55
Prokop von Caesarea 9, 42, 44, 65, 98, $199 \mathrm{f.}, 315$

Pseudo-Methodios 269

Pulcheria 52, 61 Anm. 154

Pyrrhos 23 Anm. 103, 319, $321 \mathrm{f}$.

Razadh 230, 278 Anm. 119

Romanus 143

Romulus Augustulus 27

Saul 275

Sebeos 20f., 147, 157, 164, 265, 307, 323, 328

Sergios (Patriarch) 11-14, 112f., 143 Anm. 23, 172, 184 f., 189-191, 209, 211, $218-220,223-228,236,241,256,258$, 284 f., 287f., 292f., 295-297, 310, 312, 314 Anm. 283, 319, 337

Sergios (Statthalter) 301

Severos 293-295

Shahin 152f., $178 \mathrm{f}$., $208 \mathrm{f}$.

Shahraplakan 208, 230

Shahrbaraz 177, 192, 208-210, 253f., 261 264, 277, 283, 299, 244

Smaragdus $142 \mathrm{f}$.

Sophia $58-70,168$

Sophronios 17, 19, 144, 288, 303

Stephan von Kyzikos 100

Stilicho 40, 61 Anm. 154

Tervel 332

Theoderich Strabo 53

Theoderich 76

Theodor (Herakleios' Bruder) 156f., 161, 212, 253, $301 \mathrm{f}$.

Theodor (Herakleios' Neffe) 304, 307f., 313, 318

Theodor (Comes von Abydos) 100

Theodor (Sakellarios) 302

Theodor Synkellos 14, 221-227, 248

Theodor von Sykeon 15, 144, 151, $157 \mathrm{f}$., 277

Theodora $57 \mathrm{f}$.

Theodosios I. $30 \mathrm{f} ., 38,50,74,159,162 \mathrm{f}$., 256, 308

Theodosios II. 28, 31, 50-52, 60 f., 162, 215, 297

Theodosios (Bruder des Konstans II.) 329

Theodosios (Sohn des Herakleios) $174 \mathrm{f}$. Anm. 169, 262 
Theodosios (Sohn des Maurikios) 51, 73, 76, 84 f., 87 f., 92, 111 Anm. 163, 125

Anm. 208, 140 f., 146-148, 151, 162, 164, 168, 170, 319 Anm. 5

Theophanes Confessor $22-24,70,98,100$, 113, 119, 145, 147, 149, 171-174, 202 f., 239 f., $248 f$., 256 f., 259, 276 f., 323

Theophilos von Edessa 22-25

Theophylakt Simokattes $9-11,24,75 \mathrm{f}$., $83-85,89,91,118,134-136,248,296-$ 299, 336

Theotokos 14, 100 f., 136, 218-228, 233, 236, 238, 251, 250, 310, 337

Tiberios (Sohn des Justinian II.) 332

Tiberios II. 58-61, 69-73, 75, 108 Anm. 147, 116, 168

Tiberios Apsimar 332

Turbalak 243

\subsubsection{Ortsregister}

Abydos 100

Antiochia am Orontes 94 Anm. 94, 152, 161, 176, $302 \mathrm{f}$.

Alexandria 19, 95, 165, 179, 253 Anm. 4, 287, 291, 303, 322

Alexandretta 95

Anastasis-Kirche (Jerusalem) 177, 262, 264 266., 272f., 337, 344

Anchialos 75

Apamea 152

Apostelkirche (Konstantinopel) 317

Arabissos 262

Autonomos-Kirche 90, 111

Bethlehem 273 Anm. 91, 301

Blachernen (-Viertel, -Kirche) 8 Anm. 24, 14 f., 206 Anm. 93, 212, 221, 226f., 310

Caesarea Cappadociae $\quad 152-158,208,256$ Anm. 13

Caesarea Maritima 16, 177,

Chalkedon 21 Anm. 89, 111, 125, 178, 210, 284-293, 296-299, 312, 320-322

Chrysopolis 210-310

Cotyaeum 54

Ctesiphon 16, 71, 89, 177, 179, 203, 230 f., 253, 262-263, 283, 291
Umar 269, 303, 312 Anm. 281

Urbikios 54

Valens 78, 159 Anm. 91, 308

Valentinian III. 63 Anm. 159, 125 Anm. 213, 322 Anm. 25

Valentinos $320-325$

Verina 35 Anm. 29, 52f., 127

Vitalian $55,62 \mathrm{f} ., 86,92$

Xerxes $309 \mathrm{f}$.

Yazdegerd III. 21, 304

Zacharias 16, 177, 266

Zenon 33 Anm. 22, 48, 51-54, 60 f., 70 f., 89 f., 114, 183 Anm. 206, 199 Anm. 60, 324

Zosimos 78

Zuzos 52 Anm. 111

Damaskus 176, 302

Dara $\quad 58,68,73,141,159,198$ Anm. 55

Dastagert 16,230

Dvin 20, 208, 328

Edessa $\quad 83 \mathrm{f} ., 140 \mathrm{f} ., 151 \mathrm{f} ., 253,284,286,302$

Emesa 152, 302

Felsendom (Jerusalem) $272 \mathrm{f}$.

Forum Romanum 143

Ganzak 208, $230 \mathrm{f}$.

Gaza 301

Goldenes Tor (Konstantinopel) 103, 111, 115, 126, 272

Goldenes Tor (Jerusalem) 8 Anm. 24, $272 \mathrm{f}$.

Grabeskirche $\rightarrow$ Anastasis-Kirche

Hafen (Konstantinopel) 101, 103, 111-113, 115-117, 119, 125f., 153, 334

Hagia Sophia (Konstantinopel) 13, 15, 87, 110 Anm. 155, 112, 116 f., 119, 136 Anm. 263, 139, 163, 178, 180, 189, 207, 209, 231, 233, 240, 263, Anm. 41, 301 Anm. 238, $311 \mathrm{f} ., 321,327,334,342$

Hebdomon 34, 53, 55, 90 f., 101, 107 f., 110, $114-116,118,122,124 \mathrm{f} ., 134,215,334$

Herakleia Perinthos 100, 114, $206 \mathrm{f}$. 
Hierapolis 72, 263, 285

Hiereia 256, 258f., 304-308, 311, 320

Hippodrom 47, 52, $56 \mathrm{f}$., 65, 69, 71, 86, 88, 90, 99, 108, 111, 113f., 117f., 122f., 126, 146, 148 f., 163, 171, 255-260, 311

Jerusalem 8 Anm. 24, 9, 16-19, 21, 177180, 203f., 208, 222f., 225, 234, 244, $248-250,257,261-275,279-283,288$, 291, $300 \mathrm{f} ., 303,337,344$

Johannes-Prodromos-Kirche (Hebdomon) 110, 116 Anm. 182

Kalonimon 100

Karthago 119 f., 39, 79, 93-96, 98 Anm. 92, 165, 317, 326f., 332, 334

Mardin 18

Martyropolis 73, 277 Anm. 115, 298

Mauer (Lange) 8 Anm. 23, 74, 101, 206, 210, 215,258

Mauer (Theodosianische) $8 \mathrm{Anm} .24,28,34$, $44,80,86-89,91-93,111,114$ f., $210-$ $212,219,221,224,259,310$

Monokarton 81, 83

Mren 8 Anm. 24, $268 \mathrm{f}$.

Nikaia 289

Nikomedia 191, 207

Niniveh 230, 252

\subsubsection{Stellenregister}

Acta Anastasii Persae

$\begin{array}{ll}-8 & 179\end{array}$

$-43 \quad 232,254$

Agapius

- Vasiliev 454301

- Vasiliev 465232

- Vasiliev 469301

Akathistos Hymnos

- 2. proem. 15, 225, 227

Alexanderlegende

- Budge 144-158 242

- Budge 154f. 243

- Budge $158243 \mathrm{f}$.
Ölberg $\quad 267,270,303$

Pantheon 143

Partaw 208, 229

Pera 210, 310

Pylai 191

Ravenna $\quad 39,78,94,179,327$

Rom 107, 215 Anm. 213, 126, 142 f., 144, 179 Anm. 186, 254 f., 288, 329

Sebasteia 209

Stephans-Kirche (im Palast) 113, 116 f., 119, 162f., 310, 321

Sycae $\rightarrow$ Pera

Sykeon 15, 151, $157 \mathrm{f}$.

Syrakus 5, 329-331, 338

Takht-i-Sulaiman 208

Tarsos 53, 83, 127, 157

Tempelberg (Jerusalem) 8 Anm. 24, 178

Anm. 179, 265, 272-274, 279

Theodosiopolis 208, 286

Theodosius-Forum (Konstantinopel) $112 \mathrm{f}$.

Thessaloniki 15 Anm. 60, 211

Thomas-Kirche (Konstantinopel) $112 \mathrm{f}, 116 \mathrm{f}$.

Tiberias 264 Anm. 42, 270 Anm. 78

Tiflis $229 \mathrm{f}$.

Yarmouk (Schlacht am) 302-304, 309, 313, 338,340

Ammianus Marcellinus

$-20.4 .15-17 \quad 120$

Anonymus Guidi

- Nöldeke $15 \mathrm{f}$. 140, 147

- Nöldeke $28 \quad 230$

- Nöldeke 29291

- Nöldeke 31f. 263

- Nöldeke 32f. 283

Anonymus Valesianus

- 41 53, 90

Anthologia Graeca

-1.120 f. 226, 275

$-9.6558$ 
Anthologia Palatina

- 16.46f. 161

$-16.63 \mathrm{f} . \quad 198$

Antiochos Strategos

- Conybeare 504-508 177

- Conybeare $510 \quad 266$

- Conybeare 514-516 177

- Conybeare 516 171, 263f., 266, 268, 271, 282

Bibel

- Gen 14.18-20 298

- 2 Sam $6.5 \quad 274$

- 2 Sam 6.14-15 274

- 2 Sam 16-18 $276 \mathrm{f}$.

- Ps 110298

- Ez 38f. 224

- Mt 1.1-17 274

- Mt 21.1-12 270

- Mt 24.2273

- Mt $24.14 \quad 299$

- Mk 11.1-19 270

- Mk 13.2273

- Mk 13.10299

- Lk 3.23-38 274

- Lk 19.37-48 270

- Lk 21.6273

- Hebr 7.1298

- 1 Petr $5.4 \quad 204$

- Apk 20.7f. 224

Candidus, fragmenta

$\begin{array}{ll}-1 & 109\end{array}$

Cassius Dio

$-59.19 .3 \quad 309$

\section{Chronicon Paschale}

- AD 402 51, 162

- AD 53290

- AD 590 73, 76, 168

- AD $60280,85,110 \mathrm{f}$.

- AD 603 146, 148

- AD 605146

- AD 609 95, 129

- AD 610 47, 94, 101-103, 112f., 125f., 129, 132

- AD 61197,162

- AD 612 117, 129, 153, 155f., 160, 162,
- AD 613 117, 162f., 165, 169, 234

- AD 614 177f., 180

- AD $615 \quad 120,134,164,178-181$

- AD $618 \quad 180$

- AD $623 \quad 206$

- AD 624 172, 184, 208

- AD 626 209-212,

- AD 627 184, 213, 221, 228

- AD 628 12, 134, 189f., 192, 230-233, 254

Chronicon 724

- Palmer 18 262, 301

Chronicon 1234

$-91164$

$-92152 \mathrm{f}$.

-98 171f., 253

$-102253$

$-103 \quad 261,263$

$-108301$

$-110301 \mathrm{f}$.

$-111302$

- 114f. 302

$-116303$

$-117303$

$-118 \quad 287,303$

$-120 \quad 269,303$

$-139330$

Chronik von Seert

- Scher 500 f. 140 f., 148

- Scher 544544

- Scher 556263

- Scher 557f. 283

- Scher 557-560 286

- Scher 580301

Codex lustinianus

$-9.12 .1046$

Codex Theodosianus

- 3.12.1 171, 175

Collectio Avellana

- 141120

Consularia Constantinopolitana

- ad a. 386256 
Doctrina Jacobi

- Dagron/Déroche 128148

- Dagron/Déroche 31f. 287

De cerimoniis aulae Byzantinae

$-1.91108 \mathrm{f}$.

-1.92 108f., 120, 199

-1.93 55f., 109, 120

$-1.94108$

$-1.95108$

- 1 App. 75, 258

$-2.27117,167,175,276,310$

$-2.28 \quad 311$

$-2.29311$

$-2.30 \quad 314$

Evagrius, Historia ecclesistica

- $3.353,90$

$-3.4178 \mathrm{f}$.

$-5.1369$

$-6.4-6 \quad 81$

$-6.584$

$-6.9-18 \quad 81$

$-6.1772$

Eusebius, Laus Constantini

- 200.20 297

De Vita Constantini

- 1.44297

$-3.33 .1265$

$-4.22 \quad 297$

$-4.24 \quad 297$

Eutychios

- Breydy 108f. 264, 270

Exaltatio Sanctae Crucis

- 4266

$-9278$

$-17-21 \quad 267$

Reversio Sanctae Crucis

$-5266$

$-14-17 \quad 267$

Fredegar

- 4.6464

$-4.65 \quad 269,287$

$-4.66245$
Georg von Pisidien, Bellum Avaricum

$-1-15 \quad 218$

- 49f. 136

$-49-57 \quad 217$

$-58-66 \quad 210$

$-87 \quad 216$

$-96216$

$-108-124206$

$-125-129191,218$

$-130-140 \quad 219$

$-136-143218 \mathrm{f}$.

$-141-144218$

- 165-168 213, 216

$-214-225 \quad 211$

$-223-225 \quad 218$

- 226-245 211

$-237 \quad 218 \mathrm{f}$.

- 246-260 217

$-257 \mathrm{f} . \quad 215$

$-266-279 \quad 218$

$-278-283 \quad 209,218$

$-288-292 \quad 218$

-290 f. 217

$-302-306 \quad 217$

$-311-347 \quad 211$

$-313218$

- 366-373 211, 219

- 381-389 219

- 396-501 212

$-405219$

$-445 \quad 219$

$-451-456 \quad 219,222$

$-457 \quad 219$

$-493-497 \quad 219$

$-535-541 \quad 220$

Contra Severum

- 2f. 294

$-7 \quad 294$

$-9-55 \quad 294$

$-24-33293$

$-58-61 \quad 294$

$-65 \quad 294$

- 69294

$-73-75 \quad 294$

$-77 \quad 295$

$-79-84 \quad 295$

- 156f. 295

$-450-457 \quad 294$ 
$-706-712 \quad 294$

-717 f. 295

\section{Epigrammata}

- $95 \mathrm{f} . \quad 226$

Expeditio Persica

-1.17-19 193

$-1.35-50 \quad 189,193$

$-1.49201$

-1. 104-111 187

$-1.112-125$ 181, 186f., 191, 193

$-1.126193$

$-1.129193$

-1.132-138 191

$-1.139-151 \quad 192,203$

$-2.8-11192$

$-2.19193$

$-2.39-65192$

$-2.85 \mathrm{f} . \quad 203$

- 2. 88-97 203

$-2.103-106203$

$-2.105-115 \quad 203$

$-2.113-115 \quad 277$

$-2.116-148 \quad 192$

$-2.122-126 \quad 192$

$-2.163-169192$

$-2.163-174203$

$-2.206-3.304192$

$-2.235 \mathrm{f} . \quad 194$

-2.239 f. 194

$-2.244 \quad 194$

$-2.252 \quad 194,203$

$-2.304-326309$

$-3.48-53194$

-3.87 f. 195

$-3.92194$

- 3.93-124 $195 \mathrm{f}$.

$-3.305-321192$

$-3.112-115 \quad 280$

$-3.333238$

$-3.385194$

$-3.401194$

$-3.407-410 \quad 201$

\section{Heraclias}

$-1.65-70239$

-1.71-73 135, 239

$\begin{array}{ll}-1.82-84 & 239\end{array}$

$-1.84-92 \quad 239$

$$
\begin{aligned}
& \text { - } 1.93-98 \quad 236 \\
& -1.98-102 \quad 207 \\
& -1.110-121236 \\
& -1.131-139236 \\
& -1.143-147 \quad 238 \\
& -1.148 \quad 136 \\
& -1.151 \quad 136 \\
& \text { - } 1.172-218 \quad 237 \mathrm{f} \text {. } \\
& -1.201 \quad 236,250 \\
& -1.202 \quad 201 \\
& -1.212-218 \quad 236,256 \\
& -1.215 \quad 239,250 \\
& -1.216216 \\
& \begin{array}{ll}
-1.217 \quad 239 \\
-1.218
\end{array} \\
& -1.218 \quad 239 \\
& -2.5-11 \quad 136 \\
& \text { - 2.13-16 101, } 239 \\
& -2.14-23136 \\
& -2.29-33 \quad 249 \\
& -2.63-65 \quad 239 \\
& -2.83 \quad 238 \\
& -2.108-121306 \\
& -2.118-121 \quad 182 \\
& -2.122-132 \quad 181,306 \\
& -2.138 \quad 238 \\
& -2.153-230208 \\
& \text { - fragm. } 54
\end{aligned}
$$

Hexaemeron

-51-56 277

- 90 f. 277

$-1826250$

$-1829250$

$-1834 \mathrm{f} . \quad 250$

$-1836 \mathrm{f} . \quad 249 \mathrm{f}$.

In Alypium

$-117 \mathrm{f} . \quad 277$

In Bonum

-14-45 214

$-46-48 \quad 214$

$-51-55 \quad 214$

$-56-110 \quad 214$

$-58 \quad 136$

-91-101 214

- $96 \quad 136$

- 111-113 215

- 116-127 215

-160 f. 201, 214 
In Heraclium ex Africa redeuntem

$-2-14130$

$-14-38131$

$-47-60 \quad 132$

$-63-83133$

$-86-89133$

In Restitutionem S. Crucis

$-1-8 \quad 270,280$

$\begin{array}{ll}-8 & 296\end{array}$

$-16280$

$-19-26 \quad 280$

$-27-29 \quad 266$

$-27-38 \quad 280$

-30 f. 280

-41 f. 280

$-43-46280$

$-50 \mathrm{f.} \quad 281$

$-56-63281$

$-65-68 \quad 280$

$-71-77 \quad 274$

$-82-84 \quad 281$

-103 f. 190

$-104-116 \quad 264,270,280 f$.

In Resurrectionem Christi

- 106-110 215

$-112-118 \quad 215$

Laudatio Anastasii

$-15 \quad 201$

Geschichte der Patriarchen von Alexandria

- Evetts 489 f. 287

- Evetts $492 \quad 287$

Gorippus, In Laudem lustini Augusti minoris

$-1.275-287 \quad 125$

$-2.84-360109$

$-2.249-274 \quad 67$

$-2.399-406 \quad 67$

$-3.151-407 \quad 67$

$-4 \quad 67$

Gregor der Große, Epistulae

- 13.1 (Hartmann) 142

- $13.34($ Hartmann $)=13.32($ Norberg $) \quad 142$

- $13.41($ Hartmann $)=13.39($ Norberg $) \quad 142$

$-13.42($ Hartmann $)=13.40($ Norberg $) \quad 142$
Gregor von Tours, Historia Francorum

$-5.30 \quad 59$

Herodot

$-4.83-88 \quad 309$
$-7.34 f$.

$-7.34 \mathrm{ff} . \quad 309$

Johannes von Antiochia, fragmenta

$-303 \quad 44,53$

$-31681$

$-317 \quad 87$

- 318 80, 83, 90 f., 110

- 319 98, 100, 135, $148 \mathrm{f}$.

- $32144,47,100-102,112,124,126$

Johannes von Ephesus, Historia ecclesiastica

$-3.2-5 \quad 69,315$

$-5.20 \quad 80$

$-6.179$

$-6.24 \quad 67$

Johannes Lydos, De magistratibus

$-2.131$

$-3.4131$

Johannes von Nikiu

$-94.2660$

$-95.1,21 \mathrm{f} . \quad 80$

$-102.9-12 \quad 80,83$

$-103.4-8 \quad 80,110$

$-10494$

$-105 \quad 94$

$-107.1-8 \quad 95$

$-107.1695$

$-107.19-109.1795$

$-109.298$

$-109.2598$

$-109.26 \quad 100$

- 109.27-110.3 102f.

$-110.1112$

$-110.4180$

$-110.5-7 \quad 103,126$

$-110.9112 \mathrm{f}$.

$-116.3170,317$

$-119.20-24 \quad 320,322$

$-120.2320$

$-120.4322$

$-120.5-38322$

$-120.39 \mathrm{f} . \quad 320$

$-120.41-43 \quad 321 f$. 


$$
\begin{aligned}
& -120.44 \quad 321 \\
& -120.46-49 \quad 322 \\
& -120.50-55 \quad 323 \\
& -120.53 \quad 322 \\
& -120.61-63 \quad 324
\end{aligned}
$$

Justinian, Novellae

- 78.4.1 202

- 148 pr. 67

Kedrenos

- 1.685202

$-1.709149$

\section{Liber Pontificalis}

- 68143

$-69 \quad 144$

$\begin{array}{ll}-71 & 179\end{array}$

$-78329 \mathrm{f}$.

- 79331

Malalas

- 14.26322

$-14.40 \quad 44,47$

- 15.2f. 53, 90

$-15.553$

$-18.7190$

Malchos, fragmenta

- 18.3 33, 184

Marcellinus Comes, Chronicon

- ad a. 386256

- ad a. 374 53, 90

Menander Protector, fragmenta

$-14 \quad 67$

Michael Syrus

$-10.25140$

- 11.1152 f., 164

- 11.3a $171 \mathrm{f}$.

- $11.3 \quad 232,253,286$

$-11.4 \quad 287,300$

$-11.5300$

$-11.6302 \mathrm{f}$.

$-11.7 \quad 263,269,303$

$-11.10326 f$.

$-11.11329 \mathrm{f}$.

$-11.12330$
Movses Dasxuranci

$-2.9245$

$-2.10 \quad 208$

- 2.11f. 229

$-2.12 \quad 208,230$ f., 245

Nikephoros, Breviarum

- 1 98, 100-103, 112, 125f., 148

- 2 44, 112, 120, 153-156, 161, 164, 187

$-5156,161,174$

$-6-7 \quad 179$

$-8180$

$-10206$

- 11 171f., $174 \mathrm{f}$.

- 12 172, $174 \mathrm{f} ., 229$

$-13 \quad 207,210,212 \mathrm{f}$.

$-14 \quad 230,278$

- 15 231f., 234, 263

$-17 \quad 161,174,262$

- $18 \quad 257$

- 19 167, 257, 259

- $20171,278,300,308$

$-23 \quad 303$

- $24 \mathrm{f} . \quad 304 \mathrm{f} ., 308$

$-25167,174$ f., 310

$-26314$

-27 311, $314 \mathrm{f}$., $317 \mathrm{f}$.

$-28 \quad 319$

$-29319 \mathrm{f}$

$-30320 \mathrm{f}$.

- $31 \quad 320-22$

- 32 f. $\quad 315,322$

$-33 \quad 323,330$

Nikephoros Kallistos, Historia ecclesiastica $-8.32129$

Notitia dignitatum

$-1145$

Panegirici Latini

- 12[9].9.3-10.3 200

Parastaseis syntomoi chronicai

- 42.7- $10 \quad 180$

Paulus Diaconus, Historia Langobardorum

- 4.34179

$-5.11330$ 
Paulos Silentiarios, Ekphrasis

- 39199

Petros Patrikios, fragmenta

$-1372$

Prokop, De Aedificiis

- 1.2.7-12 198

- 1,7,7-11 199

$-1.10 .17-19 \quad 200$

Bellum Vandalicum

- 1.7.18 53, 90

- 1.10.18-21 202

-1.11.1- 2144

$-1.20 .21 \quad 43$

$-2.8 .1-543$

Bellum Gothicum

- 3.1.20 44

$-6.29 .17-41 \quad 43$

Bellum Persicum

$-1.24 .32-38 \quad 89$

$-1.24 .39-51 \quad 47$

$-1.25 .1799$

Historia arcana

- $12 \quad 315$

$-13.23-30199$

$-24.15 \quad 45$

Sebeos

- 31 111, 140, 147

- $33111,140,147$

$-33-34152$

- 34154 f., 157, 164f., 169, 177, 291

- 38 179, 203, 207-209, 230

-39 231f., 253, 257

$-40 \quad 261-163$

$-41 \quad 265 f ., 284,286,300,307$

$-42300$

-44 320f., $324 \mathrm{f}$.

$-47-49 \quad 328$

Sokrates, Historia ecclesiatica

- 7.18.15-18 30

$-7.23 .11 \mathrm{f} . \quad 256$
Sophronios, Anacreontica

- 14.69-102 177

$-21144 \mathrm{f}$.

Sozomenos

$-9.1 .361$

Suetonius, Caligula

-19.1-3 309

Theodor Lector, epitome

$-40153,90,114$

Theodor Synkellos, De obsidione Constantinopolis

$-2 \quad 222$

$-3223 \mathrm{f}$.

$-5 \quad 222$

$-7223 \mathrm{f}$.

$-11 \mathrm{f} . \quad 223 \mathrm{f}$.

$-13222 \mathrm{f}$.

$-14223 \mathrm{f}$.

- $15 \quad 224$

- 17 211, 219, 224

- $19 \quad 222$

- 20 f. 211, 224

$-22 \quad 212$

$-24 \quad 219$

- 32f. 212

$-33222$

- $34 \mathrm{f} ., 212$

$-37 \quad 212,277$

$-38 \mathrm{f} . \quad 222 \mathrm{f}$.

$-40-44 \quad 222$

$-46 \quad 222$

- 51f. $\quad 223-225,277$

In depositionem pretiosae vestis

- 14, 206

Theodoret, Historia religiosa

$-21.1200 \mathrm{f}$.

Theophanes Confessor, Chronographia

- AM 5967 53, 90

- AM 596953

- AM $5971 \quad 44,53$

- AM $6051 \quad 74,215$

- AM 6074 59, 70

- AM $6076 \quad 74$ 


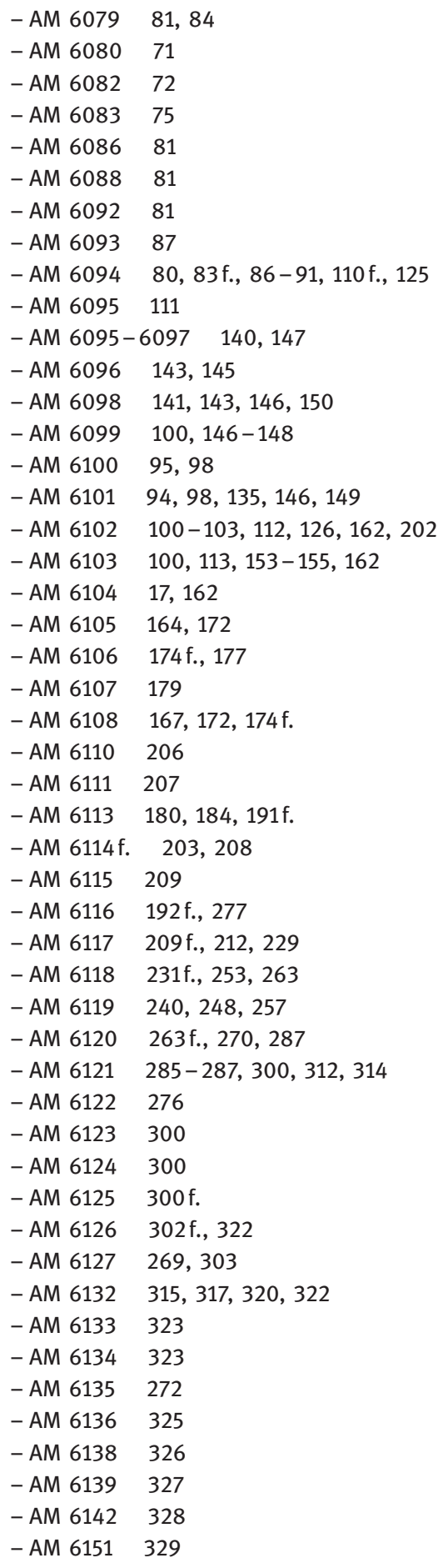

- AM $6153329 \mathrm{f}$.

- AM $6160330 \mathrm{f}$.

Theophylakt Simokattes, Dialogos

- $135,297 \mathrm{f}$.

Historiae

- 1.1.2 108

$-1.7 .274$

$-3.1-4 \quad 81$

$-3.2 .5 \quad 84$

$-3.2 .8 \quad 80$

$-3.6 .571$

$-3.11 .5-3.12 .169$

$-4.6 .1-371$

- 4.9.10.-4.10.10 72

- 4.11.1-11 72, 233

$-4.16 \quad 278$

$-4.16 .3298$

$-4.16 .23 \quad 232$

$-5.15 .5-7 \quad 248$

$-5.16 .2-4 \quad 33,181,187$

$-5.16-6.3 .875 f$.

$-5.16 .11202$

$-6.7 .6-16 \quad 81$

$-6.10 .1-3 \quad 81$

$-7.181$

$-7.13 .8-14.12 \quad 81$

$-7.15 .7 \quad 74$

$-8.1 .9-1181$

$-8.4 .10 \quad 85$

$-8.4 .11-5.4 \quad 87$

$-8.6-8.13 \quad 80$

$-8.6 .2-8.7 .6 \quad 82$

$-8.7 .7-10 \quad 83,87$

-8.7 .8 f. $\quad 86$

-8.8 .1 f. $\quad 86$

$-8.8 .3-5 \quad 84$

$-8.8 .6 \quad 86$

$-8.8 .11-8.9 .6 \quad 87 \mathrm{f}$.

$-8.9 .7 \quad 88,90,124$

$-8.9 .1090$

$-8.9 .1189 \mathrm{f}$.

$-8.9 .13-8.10 .191$

- 8.10.2-4 110, 118 f., 135

$-8.10 .6110 \mathrm{f}$.

$-8.10 .6-8.11 .6125$

-8.10 .8 f. 111

$-8.10 .13111$

-8.11 .1 f. 90 
$-8.11 .1-6 \quad 111$

$-8.11 .7-10 \quad 319$

$-8.12 .1-9 \quad 111$

$-8.12 .14 \quad 134$

- 8.13.3-6 111, 147, 164

$-8.15 .8-9 \quad 111,147,164$

Translatio corporis Sancti Anastasii Persae

$-1264 \mathrm{f}$.

Victor von Tunnuna

- s.a. 475 53, 90

- s.a. 52556

Vita S. Danielis Stylitae

- 6953,90
Vita Theodori Syceotae

- $54 \quad 144$

$-82144$

$-97 \quad 144$

$-133144$

- 140144

- 152 144, 161

- 153 151-154

- 154 153-156, 256

$-155157$

$-166157$

Zosimus

$-4.33 .1256$ 